Article

\title{
Photophysical and Biological Properties of Iridium Tetrazolato Complexes Functionalised with Fatty Acid Chains
}

\author{
Chiara Caporale ${ }^{1}$, Anna Maria Ranieri ${ }^{1}$, Silvano Paternoster ${ }^{2}{ }^{-}$, Christie A. Bader ${ }^{3}$, \\ Marco Falasca ${ }^{2}$ D , Sally E. Plush ${ }^{3}$, Douglas A. Brooks ${ }^{3} \mathbb{D}$, Stefano Stagni ${ }^{4}$ and \\ Massimiliano Massi ${ }^{1, * \mathbb{D}}$ \\ 1 School of Molecular and Life Sciences, Curtin Institute for Functional Molecules and Interfaces, Curtin \\ University, Kent Street, Bentley 6102, Australia; chiara.caporale@curtin.edu.au (C.C.); \\ anna.ranieri@curtin.edu.au (A.M.R.) \\ 2 Metabolic Signalling Group, School of Pharmacy and Biomedical Sciences, Curtin Health Innovation \\ Research Institute, Curtin University, Kent Street, Bentley 6102, Australia; \\ silvano.paternoster@curtin.edu.au (S.P.); marco.falasca@curtin.edu.au (M.F.) \\ 3 Cancer Research Institute, University of South Australia, Adelaide 5005, Australia; \\ Christie.Bader@unisa.edu.au (C.A.B.); Sally.Plush@unisa.edu.au (S.E.P.); \\ Doug.Brooks@unisa.edu.au (D.A.B.) \\ 4 Department of Industrial Chemistry "Toso Montanari”, University of Bologna, 40136 Bologna, Italy; \\ stefano.stagni@unibo.it \\ * Correspondence: m.massi@curtin.edu.au
}

Received: 28 January 2020; Accepted: 13 March 2020; Published: 26 March 2020

\begin{abstract}
Five cyclometalated $\operatorname{Ir}(\mathrm{III})$ tetrazolato complexes functionalised with fatty acid chains (octanoic, palmitic, stearic, palmitoleic, and oleic) have been synthesised. The fatty acids were chosen to evaluate the potential effect of the length and degree of unsaturation on the biological properties of the complexes for use as cellular imaging agents. The complexes were analysed in both organic and aqueous media to determine if the presence and nature of the fatty acid chains had a significant effect on their photophysical properties. The complexes display green-yellow emission in dichloromethane solutions with relatively long excited state decays, within the range 360-393 ns, and quantum yields between $5.4 \%$ and $6.7 \%$ (from degassed solutions). Temperature-dependent photophysical studies suggest that the emitting excited states of the complexes might be quenched by the thermal population of dark states. In water, the quantum yields drop within the range of $0.5 \%-2.4 \%$, and the photophysical measurements are influenced by the variable degrees of aggregation. In general, the entire series displayed low cytotoxicity and relatively high photostability, which are favourable attributes in the design of cellular imaging agents. Images of live HeLa cells were obtained for all the complexes, but those functionalised with palmitic and stearic acids had limitations due the lower solubility conferred by the saturated aliphatic chains. The complexes were mainly detected within the endoplasmic reticulum.
\end{abstract}

Keywords: iridium; fatty acids; HeLa cells; confocal imaging; lipids

\section{Introduction}

Cellular probes for optical imaging are predominantly based on fluorescent organic compounds [1-4]. While a large variety of these probes are commonly available and routinely used, there are significant shortfalls that depend on the imaging modality and cellular conditions. Commonly encountered problems are photobleaching, concentration quenching, and difficulty in discriminating probe emission 
from autofluorescence [5]. To overcome these issues and offer probes with alternative imaging properties, phosphorescent metal complexes have been increasingly investigated in the past decades. Depending on their chemical design, metal complexes can offer reduced photobleaching and are amenable to time-gated techniques to eliminate autofluorescence due to their long-lived excited states of triplet multiplicity [6].

Several examples of phosphorescent metal complexes have been used as cellular probes, especially those containing $\mathrm{Ru}(\mathrm{II}), \operatorname{Re}(\mathrm{I}), \operatorname{Ir}(\mathrm{III}), \mathrm{Au}(\mathrm{I}), \mathrm{Pt}(\mathrm{II})$, and lanthanoid cations [7-14]. Chemical design has not only allowed for the fine tuning of the photophysical properties, but it has also conferred organelle targeting, sensing, and even the development of theranostic features. The majority of metal complexes investigated so far are cationic species. This choice is commonly rationalised by the increased aqueous solubility and efficient cellular internalisation facilitated by the membrane electrical potential, but this can heavily influence the targeting of the complexes. On the other hand, neutral metal complexes have received less attention [15-17]. Our previous studies have shown that neutral metal complexes might have useful properties and constitute a class of luminescent compounds that is well worth exploring for the development of new cellular probes. Despite reduced solubility and the sometimes lower photoluminescent quantum yields, neutral complexes have comparatively displayed reduced cytotoxicity and strong interactions with lipids, particularly those contained within membranes and lipid rich organelles (e.g., endoplasmic reticulum and lipid droplets) $[18,19]$. In the case of $\operatorname{Re}(\mathrm{I})$ complexes, an unprecedented affinity for polar lipids has been reported, thus allowing the development of diagnostic tools in the area of prostate cancer [20,21]. The development of imaging agents for the detection of lipids, in general or as sub-classes, has the potential to provide important tools to study normal biological function and define different pathologies. The majority of currently available lipid dyes are organic molecules, such as Nile Red or Oil Red, which are routinely used for staining cells. Unfortunately, the staining protocols often require cell fixation, which can damage the cellular architecture and either extract lipids or change their distribution. Other organic stains, such as BODIPYTM 503/512, LipidTOX, LD540 or AIE-fluorogens [22], have been used for lipid imaging in live cells and this overcomes some of the issues related to the fixation process. Nevertheless, the availability of fluorescent or phosphorescent probes for lipids is still very limited.

We previously showed that neutral luminescent Ir(III) tetrazolato complexes can be successfully used as cellular probes for the imaging of the endoplasmic reticulum or lipid droplets [23]. We have continued this research by grafting this family of complexes to fatty acids with variable chain lengths and saturation. Here, iridium complexes appended to octanoic, palmitic, stearic, palmitoleic, and oleic acids via an amide link have been synthesised and characterised for their photophysical and biological properties.

\section{Results and Discussion}

\subsection{Synthesis of the Ligands and Iridium Complexes}

The synthetic procedures followed for the preparation of the $\mathrm{HTzPyNH}_{2}$ ligand, its corresponding $\operatorname{Ir}(\mathrm{III})$ precursor, and the family of fatty acid functionalised complexes are illustrated in Figure 1. 


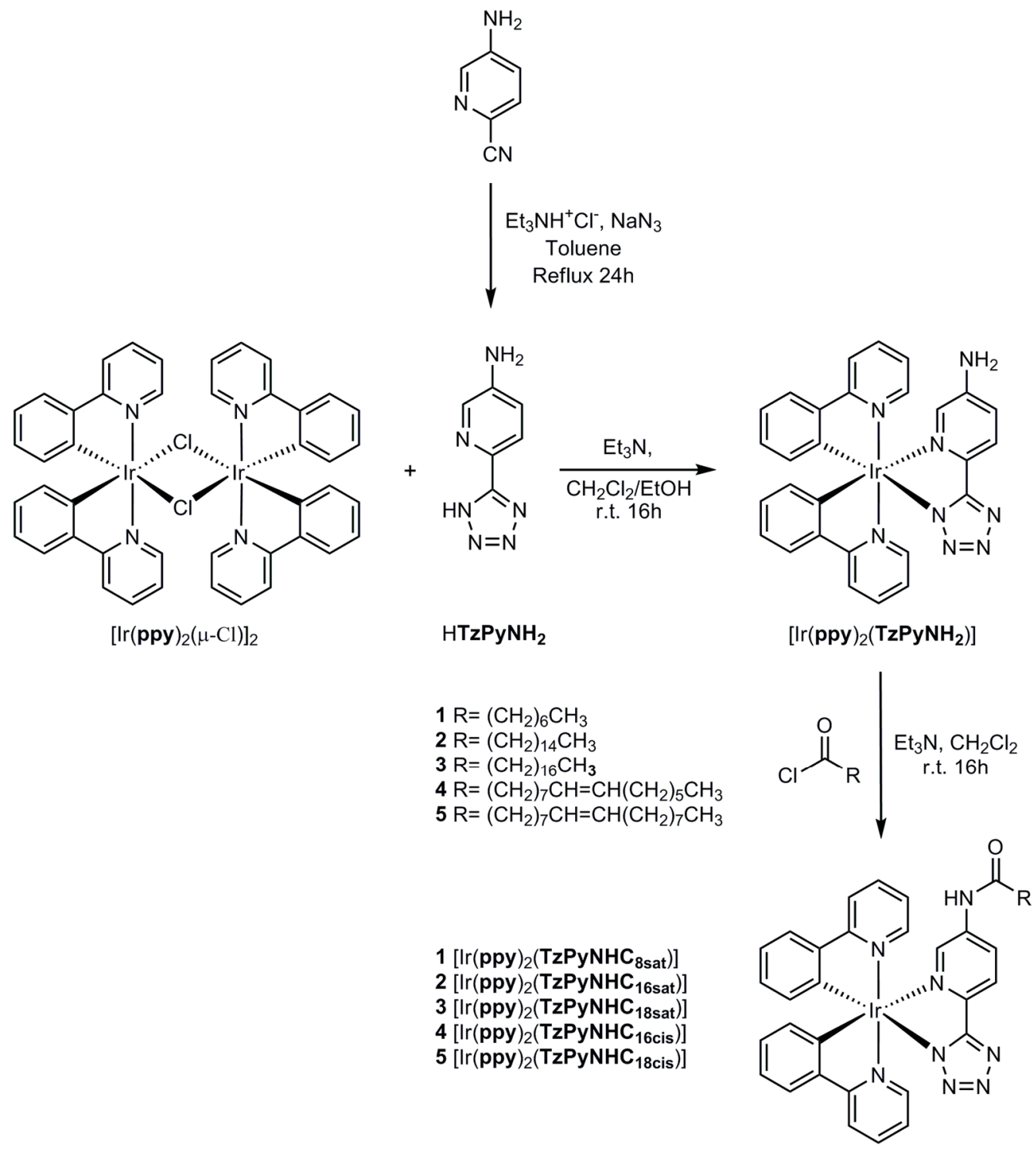

Figure 1. Summary of the synthetic procedures for the preparation of the $\mathrm{HTzPyNH}_{2}$ ligand and the fatty acid functionalised Ir complexes.

$\mathrm{HTzPyNH}_{2}$ was synthesised following the method developed by Koguro et al. [24], where 2-cyano-5-aminopyridine was reacted with sodium azide in toluene and heated at reflux in the presence of triethylammonium chloride. After extraction into an aqueous layer, the targeted compound could be easily purified by precipitation with hydrochloric acid.

The synthesis of $\left[\operatorname{Ir}(\mathbf{p p y})_{2}\left(\mathrm{TzPyNH}_{2}\right)\right]$ was adapted from previously published methods [23,25]. In this case, the addition of triethylamine to $\mathrm{HTzPyNH}_{2}$ was necessary to increase its solubility in the dichloromethane/methanol solvent mixture and facilitate its reaction with the dichloro-bridged dimer $\left[\operatorname{Ir}(\mathbf{p p y})_{2}(\mu-\mathrm{Cl})\right]_{2}$. The target $\operatorname{Ir}$ complex $\left[\operatorname{Ir}(\mathbf{p p y})_{2}\left(\mathbf{T z P y N H}_{2}\right)\right]$ could be isolated by precipitation through the addition of diethyl ether.

To prepare the series of fatty acid appended $\operatorname{Ir}(\mathrm{III})$ complexes $\left[\operatorname{Ir}(\mathbf{p p y})_{2}\left(\mathrm{TzPyNHC}_{8 \text { sat }}\right)\right]$, $\left[\operatorname{Ir}(\text { ppy })_{2}\left(\right.\right.$ TzPyNHC $\left.\left._{16 \text { sat }}\right)\right], \quad\left[\operatorname{Ir}(\text { ppy })_{2}\left(\right.\right.$ TzPyNHC $\left.\left._{18 s a t}\right)\right], \quad\left[\operatorname{Ir}(\text { ppy })_{2}\left(\right.\right.$ TzPyNHC $\left.\left._{16 \text { cis }}\right)\right]$, and $\left[\operatorname{Ir}(\text { ppy })_{2}\right.$ $($ TzPyNHC $18 c i s)$ (see Figure 1$)$, the precursor $\left[\operatorname{Ir}(\mathbf{p p y})_{2}\left(\mathbf{T z P y N H}_{2}\right)\right]$ was combined with the appropriate acetyl chloride species [26-28] and stirred in dry dichloromethane for $16 \mathrm{~h}$ and in the presence of triethylamine. 
The synthesised ligand and Ir complexes were characterised by means of NMR (see Supplementary Materials for all the ${ }^{1} \mathrm{H}$ and ${ }^{13} \mathrm{C}$ NMR spectra) and IR spectroscopy, high-resolution mass spectrometry (see Supplementary Materials for all the spectra), as well as elemental analysis.

\subsection{Photophysical Properties}

The photophysical properties of the synthesised Ir complexes, which were measured from diluted dichloromethane and aqueous solutions $\left(\approx 10^{-5} \mathrm{M}\right.$ ), have been summarised in Table 1 (see the Supplementary Materials for photophysical data in lysosomal $\mathrm{pH}$ fluid solution, phosphate buffer saline (PBS), and ethyl laurate). The choice of the various solvents was aimed to potentially simulate different hydrophilic and lipophilic cellular environments. The aqueous solutions also contain $2 \%$ of DMSO to favour the complete dissolution of the Ir complexes.

Table 1. Photophysical data of the reported iridium complexes from air-equilibrated and degassed dichloromethane as well as air-equilibrated aqueous solutions $\left(\approx 10^{-5} \mathrm{M}\right)$.

\begin{tabular}{|c|c|c|c|c|c|}
\hline Complex & Solvent ${ }^{a}$ & $\begin{array}{c}\lambda_{\mathrm{abs}}(\mathrm{nm}) \\
\left(10^{4} \varepsilon\left[\mathrm{M}^{-1} \mathrm{~cm}^{-1}\right]\right)\end{array}$ & $\begin{array}{c}\lambda_{\mathrm{em}} \\
(\mathrm{nm})\end{array}$ & $\begin{array}{c}\tau_{\text {aer }} \\
\tau_{\text {deaer }} \\
(\mathrm{ns})^{b}\end{array}$ & $\begin{array}{c}\Phi_{\text {aer }}{ }^{c} \\
\Phi_{\text {deaer }}{ }^{c}\end{array}$ \\
\hline \multirow{2}{*}{$\begin{array}{c}{\left[\operatorname{Ir}(\text { ppy })_{2}\right.} \\
\left.\left(\mathrm{TzPyNH}_{2}\right)\right]\end{array}$} & $\mathrm{CH}_{2} \mathrm{Cl}_{2}$ & 270 (9.45), 346 (1.79), 387 (0.89), 423 (0.53) & 484,514 & $\begin{array}{c}101 \\
1032\end{array}$ & $\begin{array}{l}0.005 \\
0.028\end{array}$ \\
\hline & $\mathrm{H}_{2} \mathrm{O}$ & $273(5.30), 388(0.91), 422(0.56)$ & 484,508 & $30(3), 466(97)$ & 0.012 \\
\hline \multirow{2}{*}{$\begin{array}{c}{\left[\operatorname{Ir}(\text { ppy })_{2}\right.} \\
\left.\left(\text { TzPyNHC }_{8 \text { sat }}\right)\right]\end{array}$} & $\mathrm{CH}_{2} \mathrm{Cl}_{2}$ & 264 (8.30), $364(0.46), 420(0.26)$ & 500,514 & $\begin{array}{c}83 \\
393\end{array}$ & $\begin{array}{l}0.006 \\
0.067\end{array}$ \\
\hline & $\mathrm{H}_{2} \mathrm{O}$ & 287 (4.17), 393 (1.56), 426 (1.20) & 493,520 & $55(81), 277(19)$ & 0.004 \\
\hline \multirow{2}{*}{$\begin{array}{c}{\left[\operatorname{Ir}(\text { ppy })_{2}\right.} \\
\left.\left(\text { TzPyNHC }_{16 \text { sat }}\right)\right]\end{array}$} & $\mathrm{CH}_{2} \mathrm{Cl}_{2}$ & 264 (7.91), $386(0.29), 423(0.15)$ & 500,530 & $\begin{array}{c}80 \\
374 \\
\end{array}$ & $\begin{array}{l}0.006 \\
0.067\end{array}$ \\
\hline & $\mathrm{H}_{2} \mathrm{O}$ & $280(2.63), 392(0.45), 433(0.28)$ & 495,526 & $53(43), 197(57)$ & 0.009 \\
\hline \multirow{2}{*}{$\begin{array}{c}{\left[\operatorname{Ir}(\text { ppy })_{2}\right.} \\
\left.\left(\text { TzPyNHC }_{18 \text { sat }}\right)\right]\end{array}$} & $\mathrm{CH}_{2} \mathrm{Cl}_{2}$ & $264(8.31), 386(0.36), 422(0.20)$ & 502,526 & $\begin{array}{c}83 \\
383 \\
\end{array}$ & $\begin{array}{l}0.007 \\
0.060 \\
\end{array}$ \\
\hline & $\mathrm{H}_{2} \mathrm{O}$ & 281 (5.27), 393 (2.22), 452 (1.77) & 498,530 & 195 (57), 999 (43) & 0.024 \\
\hline \multirow{2}{*}{$\begin{array}{c}{\left[\operatorname{Ir}(\text { ppy })_{2}\right.} \\
\left.\left(\text { TzPyNHC }_{16 \text { cis }}\right)\right]\end{array}$} & $\mathrm{CH}_{2} \mathrm{Cl}_{2}$ & $264(8.24), 386(0.36), 421(0.21)$ & 496,548 & $\begin{array}{c}75 \\
356 \\
\end{array}$ & $\begin{array}{l}0.007 \\
0.054 \\
\end{array}$ \\
\hline & $\mathrm{H}_{2} \mathrm{O}$ & $284(6.38), 397(1.33), 435(0.84)$ & 496,548 & $70(25), 946(75)$ & 0.009 \\
\hline \multirow{2}{*}{$\begin{array}{c}{\left[\operatorname{Ir}(\mathbf{p p y})_{2}\right.} \\
\left.\left(\text { TzPyNHC }_{18 \text { cis }}\right)\right]\end{array}$} & $\mathrm{CH}_{2} \mathrm{Cl}_{2}$ & $264(7.16), 386(0.26), 418(0.15)$ & 493,537 & $\begin{array}{c}75 \\
360 \\
\end{array}$ & $\begin{array}{l}0.008 \\
0.060 \\
\end{array}$ \\
\hline & $\mathrm{H}_{2} \mathrm{O}$ & $282(6.04), 394(1.28), 431(0.85)$ & 496,547 & 34 (59), 339 (41) & 0.005 \\
\hline
\end{tabular}

${ }^{a}$ Aqueous solvents contain $2 \%$ DMSO. ${ }^{\mathrm{b}}$ For the biexponential excited state lifetime $(\tau)$, the relative weights of the exponential curves are reported in parentheses. ${ }^{c}$ Measured versus $\left[\mathrm{Ru}(\mathbf{b p y})_{3}\right] \mathrm{Cl}_{2}$ in $\mathrm{H}_{2} \mathrm{O}\left(\Phi_{\mathrm{r}}=0.028\right)[29]$.

In general, the absorption profiles in dichloromethane solutions are consistent along the whole series, suggesting that the presence and nature of the fatty acid chain does not affect the absorption properties of these complexes (Figure 2). The complexes exhibit intense spin-allowed ligand-centred (LC) $\pi-\pi^{*}$ absorption features in the UV region $(250-315 \mathrm{~nm}$ ) and weaker absorption bands at $\lambda \geq 350 \mathrm{~nm}$, which can be assigned to a mixture of spin-allowed ligand-to-ligand (LLCT) and metal-to-ligand charge transfer (MLCT) transitions. The weak absorption tailing beyond $400 \mathrm{~nm}$ has been assigned to spin-forbidden MLCT/LLCT transitions, with reference to previous spectroscopic studies of related Ir(III) tetrazolato complexes [23,25,30]. The absorption bands in the remaining solvents are reported in the Supplementary Materials and follow similar trends, although in some cases, the spectra are visibly affected by the poor solubility of the complexes, potentially leading to aggregation. 


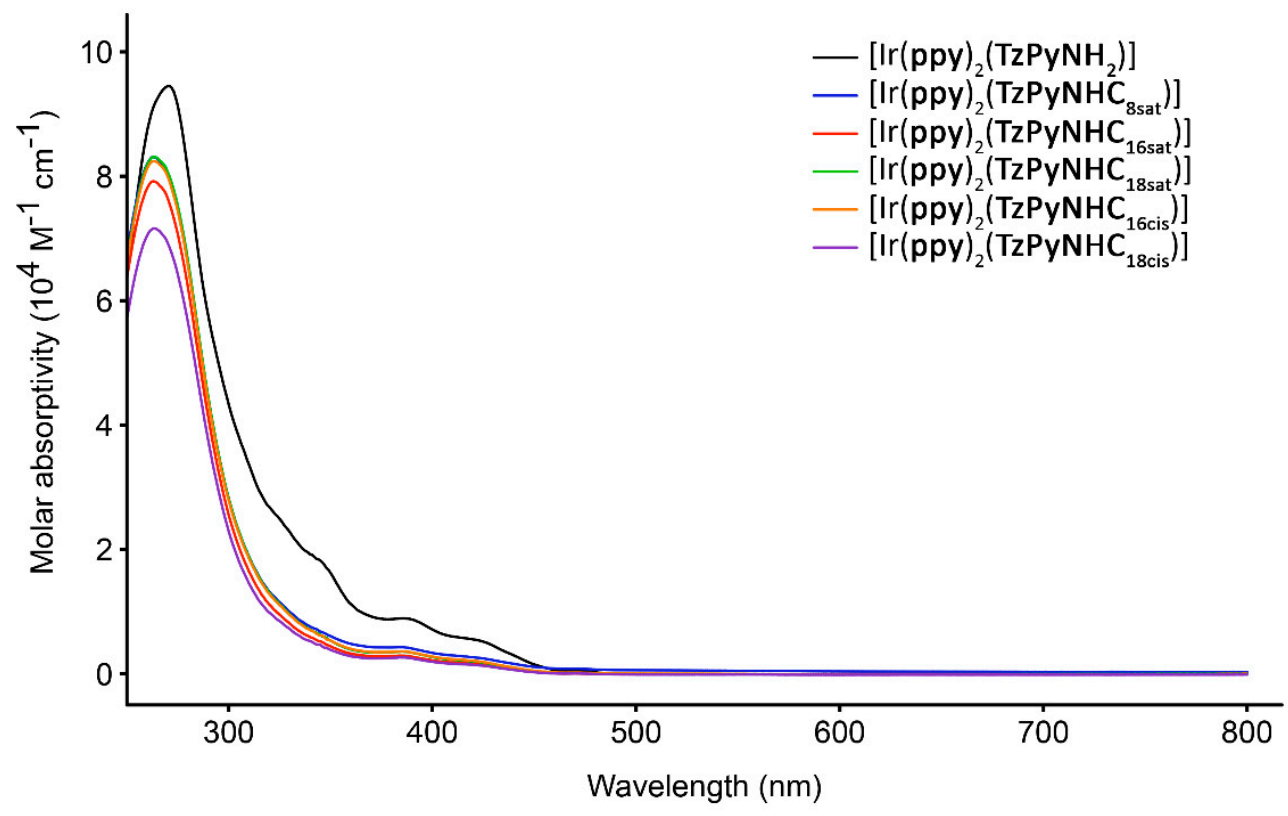

Figure 2. Absorption spectra of the iridium complexes from $10^{-5} \mathrm{M}$ dichloromethane solutions.

Selected emission spectra for $\left[\operatorname{Ir}(\mathbf{p p y})_{2}\left(\mathrm{TzPyNHC}_{\mathbf{1 6 s a t}}\right)\right]$ and $\left[\operatorname{Ir}(\mathbf{p p y})_{2}\left(\mathrm{TzPyNHC}_{\mathbf{1 6 c i s}}\right)\right]$ are shown in Figure 3, with the remaining spectra shown in the Supplementary Materials. In general, photoexcitation at $\lambda_{\mathrm{ex}}=350 \mathrm{~nm}$ resulted in broad bands, corresponding to emission in the green-yellow region. All of the complexes measured from dichloromethane solutions are characterised by very similar and vibronically structured emission bands, with vibronic progression spaced around $1200 \mathrm{~cm}^{-1}$. This feature suggests emission from charge transfer excited states $\left({ }^{3} \mathrm{LLCT} /{ }^{3} \mathrm{MLCT}\right)$ mixed with ligand-centred excited states $\left({ }^{3} \mathrm{LC}\right)$ [31-34]. As expected from the similarities of the absorption spectra, the length and degree of unsaturation of the fatty acid chains does not appear to affect the photophysical properties of these complexes when compared to their precursor $\left[\operatorname{Ir}(\mathbf{p p y})_{2}\left(\mathrm{TzPyNH}_{2}\right)\right]$ in dichloromethane solutions.

The emission of the Ir complexes is sensitive to the presence of molecular oxygen, suggesting phosphorescent emission from excited states of triplet multiplicity $[35,36]$. In fact, upon deoxygenation of the dichloromethane solutions, an increase of the quantum yield $\Phi$ and elongation of the excited state lifetime $\tau$ was recorded (Table 1). The values of excited state lifetimes are comparable for all the Ir complexes. The data can be nicely fitted with monoexponential functions from dichloromethane solutions. In the remaining solvents, excited state decays could be fitted with biexponential functions.

To a variable degree, the emission profiles in the various aqueous solvents and ethyl laurate displayed the appearance of red-shifted bands (see the Supplementary Materials), which is a behaviour that could be ascribed to a combination of solvatochromism (lowering of the energy of the charge transfer excited states upon increased solvent polarity) and/or different extents of aggregation. 


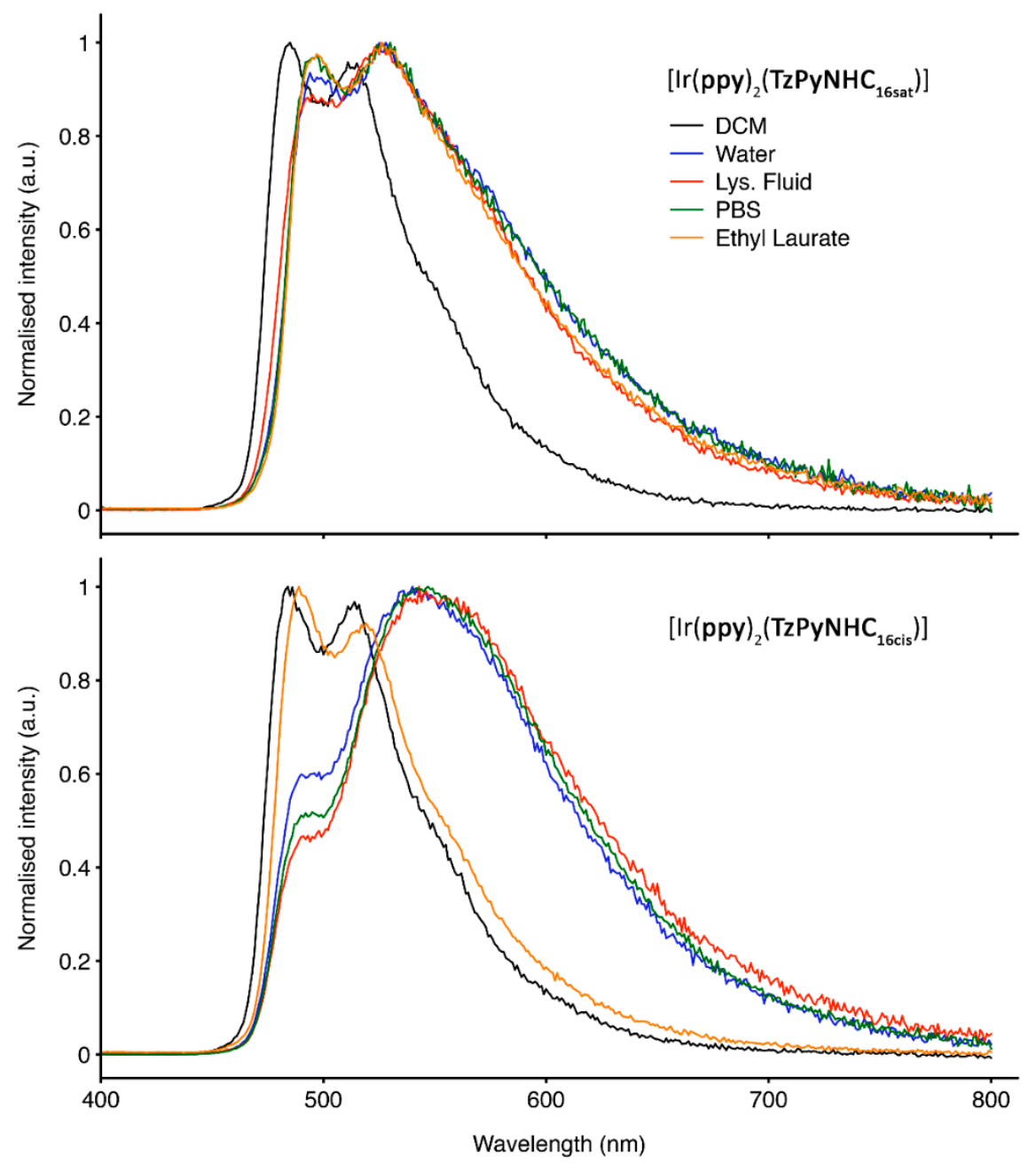

Figure 3. Emission spectra of $\left[\operatorname{Ir}(\mathbf{p p y})_{2}\left(\mathrm{TzPyNHC}_{\mathbf{1 6 s a t}}\right)\right]$ (top) and $\left[\operatorname{Ir}(\mathbf{p p y})_{2}\right.$ (TzPyNHC $\left.\left._{\mathbf{1 6 c i s}}\right)\right]$ (bottom) from diluted solutions with excitation at $350 \mathrm{~nm}$.

\subsection{Temperature-Dependent Emission Lifetimes}

We have previously published an analogous Ir complex bearing a nitrile substituent in the 5 position of the pyridine ring [23], $\left[\operatorname{Ir}(\mathbf{p p y})_{2}(\operatorname{TzPyCN})\right]$, as opposed to the currently reported complexes bearing an amine/amide group in the same position. When comparing measurements from dichloromethane solutions, the emission profile of $\left[\operatorname{Ir}(\mathbf{p p y})_{2}(\mathrm{TzPyCN})\right]$ was red-shifted (typical broad and structureless ${ }^{3} \mathrm{MLCT}$ emission with a maximum at $618 \mathrm{~nm}$ ) compared to the emission profiles of the complexes bearing an amine/amide group. This trend can be easily rationalised by taking into account the electron-withdrawing nature of the nitrile substituent, stabilising the $\pi^{*}$ system of the pyridyltetrazolato ligand. In contrast, $\left[\operatorname{Ir}(\mathbf{p p y})_{2}(\mathrm{TzPyCN})\right]$ displayed a greater quantum yield and longer excited state lifetime decay, which is a trend that is opposing the energy gap law [37]. In an effort to understand the different photophysical properties, temperature-dependent luminescence lifetime measurements were performed in air-equilibrated dichloromethane solutions comparing $\left[\operatorname{Ir}(\mathbf{p p y})_{2}(\mathrm{TzPyCN})\right]$ with $\left[\operatorname{Ir}(\mathbf{p p y})_{2}\left(\mathrm{TzPyNH}_{2}\right)\right]$ and $\left[\operatorname{Ir}(\mathbf{p p y})_{2}\left(\mathrm{TzPyNHC}_{\mathbf{1 6}} \mathbf{P i s}\right)\right]$, which were selected as two representative complexes bearing an amine/amide substituent. The measurements were performed at selected temperature values between 198 and $298 \mathrm{~K}$. The data have been plotted as the logarithm of the rate constant $k_{\mathrm{obs}}$, which was calculated as the inverse of the lifetime $\tau^{-1}$, against the inverse of the temperature, $T^{-1}$, following an Arrhenius-type function as (Figure 4). 


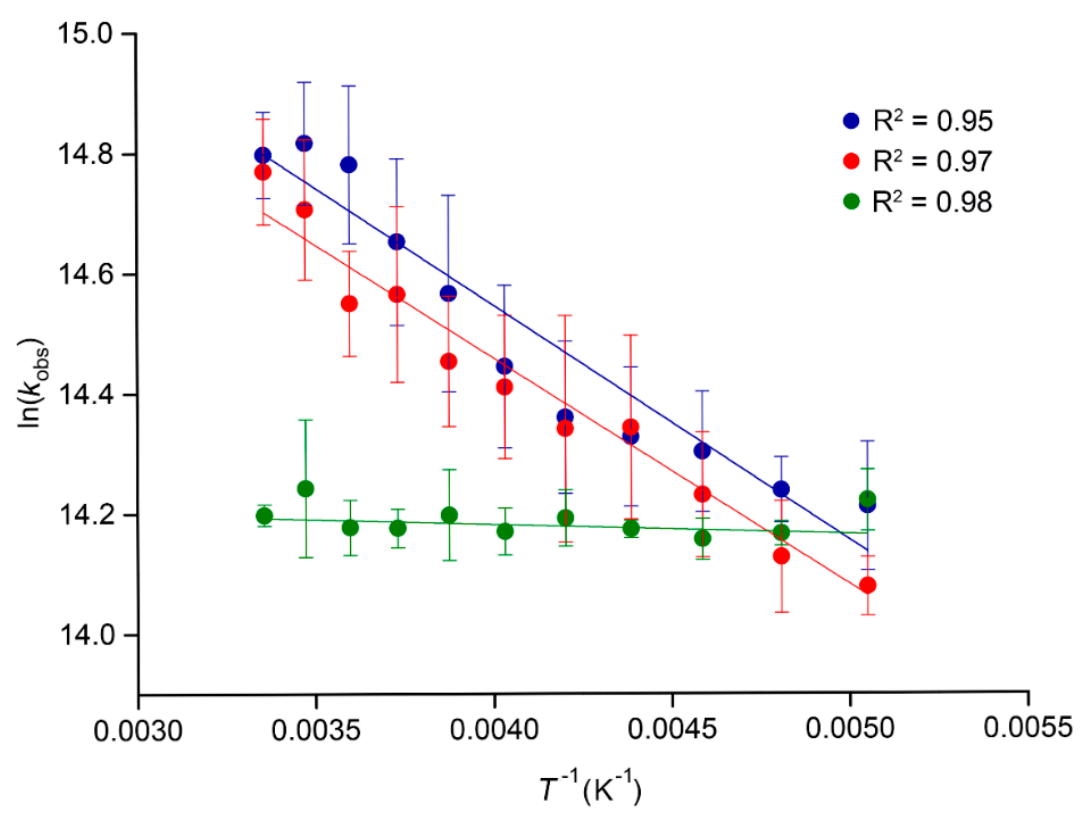

Figure 4. Arrhenius plot for $\left[\operatorname{Ir}(\mathbf{p p y})_{2}\left(\mathrm{TzPyNHC}_{16 \mathrm{cis}}\right)\right]$ (blue), $\left[\operatorname{Ir}(\mathbf{p p y})_{2}\left(\mathrm{TzPyNH}_{2}\right)\right]$ (red), and $\left[\operatorname{Ir}(\mathbf{p p y})_{2}(\mathrm{TzPyCN})\right]$ (green), obtained from measurements in air-equilibrated diluted dichloromethane solutions. Error bars are reported as standard deviation of three independent measurements.

Figure 4 suggests that the trend of the excited state lifetime decay against temperature for the complexes follow an Arrhenius-type law. The slopes of the fitting functions for $\left[\operatorname{Ir}(\mathbf{p p y})_{2}\left(\mathrm{TzPyNH}_{2}\right)\right]$ and $\left[\operatorname{Ir}(\mathbf{p p y})_{2}\left(\mathrm{TzPyNHC}_{\mathbf{1 6}} \mathbf{\text { cis }}\right)\right]$ are very similar, and they are distinctly different from that of $\left[\operatorname{Ir}(\mathbf{p p y})_{2}(\mathrm{TzPyCN})\right]$. For the latter, the excited state lifetime decay does not seem to significantly change across the range of temperatures 198 to $298 \mathrm{~K}$. On the other hand, the data suggest that both $\left[\operatorname{Ir}(\mathbf{p p y})_{2}\left(\mathbf{T z P y N H}_{2}\right)\right]$ and $\left[\operatorname{Ir}(\mathbf{p p y})_{2}\left(\mathbf{T z P y N H C}_{\mathbf{1 6 c i s}}\right)\right]$ are deactivated by the thermal population of higher lying excited states $[38,39]$. This conclusion is consistent with the fact that the emissive excited states of $\left[\operatorname{Ir}(\mathbf{p p y})_{2}\left(\mathbf{T z P y N H}_{2}\right)\right]$ and $\left[\operatorname{Ir}(\mathbf{p p y})_{2}\left(\mathbf{T z P y N H C}_{\mathbf{1 6}} \mathbf{z i s}\right)\right]$ are higher in energy with respect to $\left[\operatorname{Ir}(\mathbf{p p y})_{2}(\mathrm{TzPyCN})\right]$, and therefore the energy gap to quenching higher lying states is smaller.

\subsection{Lipophilicity}

The lipophilicity of the complexes was measured by the shake-flask method, using a $\mathrm{pH}=7.4$ buffered PBS solution and n-octanol [40]. All the $\log \mathrm{D}_{7.4}$ values have been summarised in Table 2 . $\left[\operatorname{Ir}(\mathbf{p p y})_{2}\left(\mathrm{TzPyNH}_{2}\right)\right]$ possesses a value of 1.99 , which is within the range of previously reported $\operatorname{Ir}(\mathrm{III})$ cyclometalated species [23,41-45]. As expected, by functionalising the complex with the fatty acid chains, the values increased to 2.26-2.84 [46,47]. The complexes $\left[\operatorname{Ir}(\mathbf{p p y})_{2}\left(\mathrm{TzPyNHC}_{\mathbf{1 6 c i s}}\right)\right]$ and $\left[\operatorname{Ir}(\mathbf{p p y})_{2}\left(\mathrm{TzPyNHC}_{18 \mathrm{sis}}\right)\right]$ showed slightly lower values of $\log \mathrm{D}_{7.4}$ with respect to the remaining functionalised complexes, which could be ascribed to the presence of the kink in the aliphatic chain with cis configuration [48]. Surprisingly, the length of the fatty acid chain does not seem to significantly affect the lipophilicity of these complexes, even when comparing $\left[\operatorname{Ir}(\mathbf{p p y})_{2}\left(\mathrm{TzPyNHC}_{8 \text { sat }}\right)\right]\left(\log \mathrm{D}_{7.4}=\right.$ 2.66) with $\left[\operatorname{Ir}(\mathbf{p p y})_{2}\left(\right.\right.$ TzPyNHC $\left.\left._{18 s a t}\right)\right]\left(\log \mathrm{D}_{7.4}=2.63\right)$. 
Table 2. Distribution coefficient values $\left(\log \mathrm{D}_{7.4}\right)$ for the reported iridium complexes.

\begin{tabular}{|c|c|}
\hline Complexes & $\log D_{7.4}$ \\
\hline$\left[\operatorname{Ir}(\mathbf{p p y})_{2}\left(\mathrm{TzPyNH}_{2}\right)\right]$ & $1.99 \pm 0.04$ \\
\hline$\left[\operatorname{Ir}(\mathbf{p p y})_{2}\left(\mathrm{TzPyNHC}_{8 \mathrm{sat}}\right)\right]$ & $2.66 \pm 0.07$ \\
\hline$\left[\operatorname{Ir}(\mathbf{p p y})_{2}\left(\right.\right.$ TzPyNHC $\left.\left._{16 s a t}\right)\right]$ & $2.84 \pm 0.08$ \\
\hline$\left[\operatorname{Ir}(\mathbf{p p y})_{2}\left(\right.\right.$ TzPyNHC $\left.\left._{18 s a t}\right)\right]$ & $2.63 \pm 0.06$ \\
\hline$\left[\operatorname{Ir}(\mathbf{p p y})_{2}\left(\mathrm{TzPyNHC}_{\mathbf{1 6}} \mathbf{p i s}\right)\right]$ & $2.31 \pm 0.06$ \\
\hline$\left[\operatorname{Ir}(\mathbf{p p y})_{2}\left(\mathrm{TzPyNHC}_{18 \mathrm{cis}}\right)\right]$ & $2.26 \pm 0.06$ \\
\hline
\end{tabular}

\subsection{Cellular Internalisation and Localisation}

The cellular internalisation of the complexes was investigated in live HeLa cells via confocal microscopy, using single photon excitation at $403 \mathrm{~nm}$ (Figure 5). The Ir complexes were incubated at a concentration of $5 \mu \mathrm{M}$, with $2 \%$ DMSO required in the RPMI-1640 culture medium to prevent extensive precipitation. Even with the addition of the DMSO, the presence of precipitated complex is evident for the complexes bearing $16-\mathrm{C}$ and $18-\mathrm{C}$ chains. Furthermore, it is noted that the complexes functionalised with saturated $16-\mathrm{C}$ and $18-\mathrm{C}$ chains were significantly less efficient in penetrating the cell membrane. Given the similar values of lipophilicity, these differences might be ascribed to the variable degree of aggregation and solubility. These two complexes were not explored any further in imaging experiments.

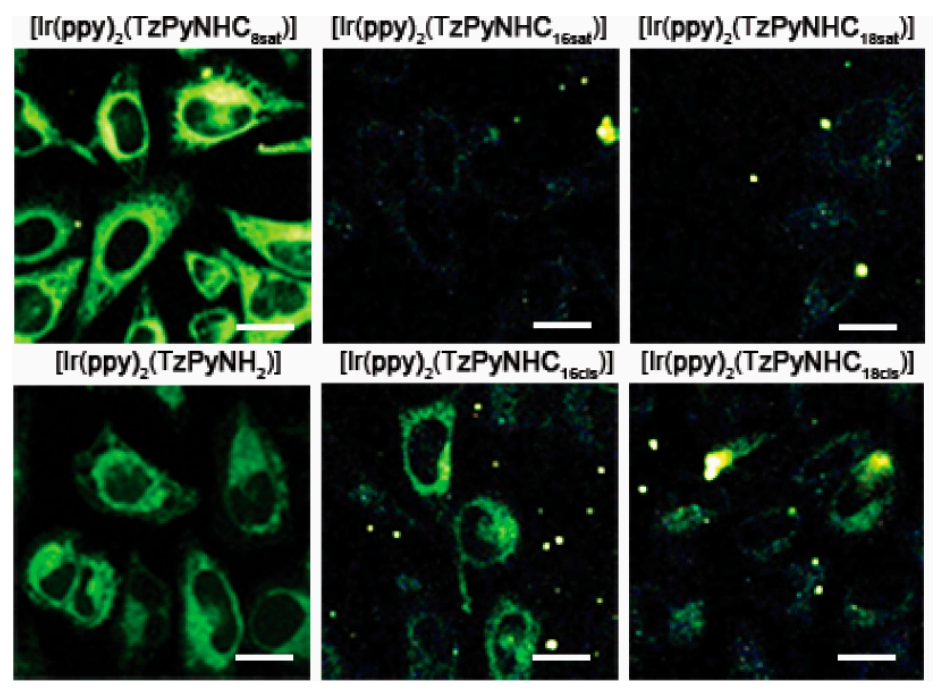

Figure 5. Micrographs of live HeLa cells stained with $5 \mu \mathrm{M}$ of the reported iridium complexes. Scale bar $=20 \mu \mathrm{m}$.

The obtained confocal images (Figure 5) revealed evidence of the internalisation of $\left[\operatorname{Ir}(\mathbf{p p y})_{2}\left(\mathrm{TzPyNHC}_{8 \mathrm{sat}}\right)\right]$ and $\left[\operatorname{Ir}(\mathbf{p p y})_{2}\left(\mathrm{TzPyNH}_{2}\right)\right]$, and to a lesser extent $\left[\operatorname{Ir}(\mathbf{p p y})_{2}\left(\mathrm{TzPyNHC}_{\mathbf{1 6}} \mathbf{P i s}\right)\right]$ and $\left[\operatorname{Ir}(\mathbf{p p y})_{2}\left(\mathrm{TzPyNHC}_{18 \mathrm{sis}}\right)\right]$. To confirm that the detected signal belonged to the phosphorescent emission of the Ir complexes, the spectral profiles were recorded directly from the live cells (see Supplementary Materials). The maxima are consistent with the photophysical data measured from aqueous solutions (Table 1), and they are well distinct from the maxima belonging to the autofluorescence recorded in the $444-453 \mathrm{~nm}$ region. The complexes were found to accumulate in the perinuclear region, with staining patterns resembling the endoplasmic reticulum, as observed for previously reported Ir tetrazolato complexes [23]. 


\subsection{Cell Viability Assay}

To assess whether the Ir complexes showed any cytotoxic effects (without photoexcitation), HEK293-T cells were treated at 20 and $40 \mu \mathrm{M}$ concentrations for 2 and $24 \mathrm{~h}$, followed by cell viability assessment with Alamar Blue reduction reagent. The complexes did not show significant cytotoxicity in any of the incubation conditions, as depicted in Figure 6. Interestingly, only a few examples of metal complexes appended with fatty acid or simple alkyl chains have been investigated for biological applications. When reported, the cytotoxicity studies of related $\operatorname{Ir}(\mathrm{III}), \operatorname{Re}(\mathrm{I})$, and $\operatorname{Ru}(\mathrm{II})$ probes have showed moderate to high cytotoxicity in live cells [46,49-53]. These complexes are all cationic, which is a feature that is usually associated with enhanced solubility and cellular internalisation. The trend reinforces the previously observed behaviour that neutral complexes might exhibit reduced cytotoxicity when internalised into live cells when compared to chemically analogous cationic species. In particular, cationic Ir complexes bearing a long alkyl chain in their ancillary bipyridine ligand exhibit higher toxicity $\left(\mathrm{IC}_{50}=12.0\right.$ and $2.0 \mu \mathrm{M}$, respectively) than cisplatin $\left(\mathrm{IC}_{50}=18.1 \mu \mathrm{M}\right)$ in the same experimental conditions $[46,49]$. Based on these results, the low cytotoxicity of the fatty acid functionalised Ir probes confirms their suitability to be exploited as non-toxic optical markers to image live cells.

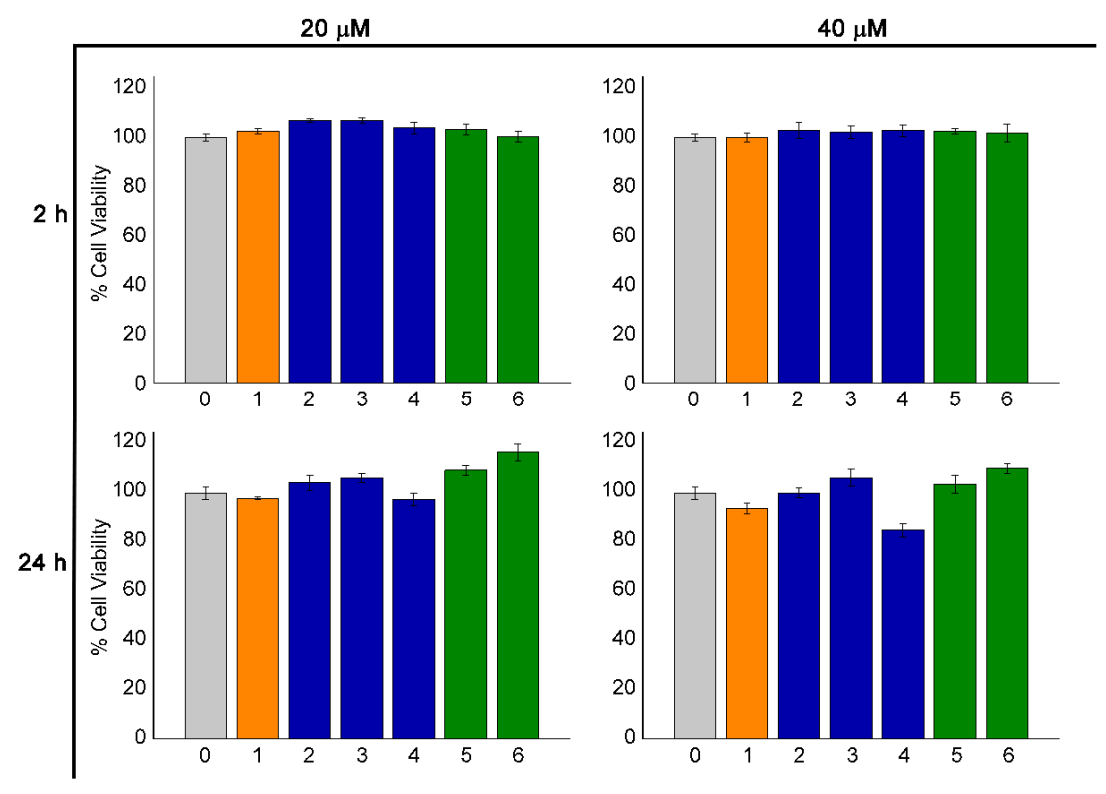

Figure 6. Cell viability after 2 and $24 \mathrm{~h}$ incubation with the iridium complexes at 20 and 40 $\mu$ M. (0) Control (2\% DMSO in Dulbecco's Modified Eagle medium): (1) [ $\operatorname{Ir}(\mathbf{p p y})_{2}\left(\mathrm{TzPyNH}_{2}\right)$ ]; (2) $\left[\operatorname{Ir}(\mathbf{p p y})_{2}\left(\mathrm{TzPyNHC}_{\mathbf{8 s a t}}\right)\right] ;$ (3) $\left[\operatorname{Ir}(\mathbf{p p y})_{2}\left(\mathbf{T z P y N H C}_{\mathbf{1 6 s a t}}\right)\right] ; \quad$ (4) $\left[\operatorname{Ir}(\mathbf{p p y})_{2}\left(\right.\right.$ TzPyNHC $\left.\left._{\mathbf{1 8 s a t}}\right)\right]$; (5) $\left[\operatorname{Ir}(\mathbf{p p y})_{2}\left(\right.\right.$ TzPyNHC $\left.\left._{16 \text { cis }}\right)\right] ;(6)\left[\operatorname{Ir}(\mathbf{p p y})_{2}\left(\right.\right.$ TzPyNHC $\left.\left._{\mathbf{1 8 c i s}}\right)\right]$.

\subsection{Photostability}

Luminescent transition metal complexes for application in biological imaging have frequently shown an improved photostability compared to conventional organic fluorophores, which is advantageous when the continuous monitoring of biological processes is required or for real-time tracking applications [54-58]. For this reason, the photostability of imaging agents is one of the major requirements, along with low cytotoxicity, high localisation specificity, and good solubility in an aqueous environment. Thus, the photostability of the Ir complexes was assessed. The complexes were dissolved in PBS solution (2\% DMSO) and irradiated using a Pen-Ray Mercury Lamp source at $365 \mathrm{~nm}$ for $900 \mathrm{~s}$. The variation in emission intensity was recorded with a time frame of $30 \mathrm{~s}$. Both the amino and fatty acid-appended complexes exhibited relatively high resistance to photobleaching, as reported in Figure 7. The complexes functionalised with fatty acids chains display less than $40 \%$ reduction of their initial intensity after 600 s. On the other hand, $\left[\operatorname{Ir}(\mathbf{p p y})_{2}\left(\mathbf{T z P y N H} \mathbf{N H}_{2}\right)\right]$ exhibits greater photostability, 
with final emission intensity only reduced by $25 \%$ from the initial value. The photostability of this series of fatty acid-functionalised complexes is comparable with values previously recorded for other neutral Ir complexes developed by our research group [23].

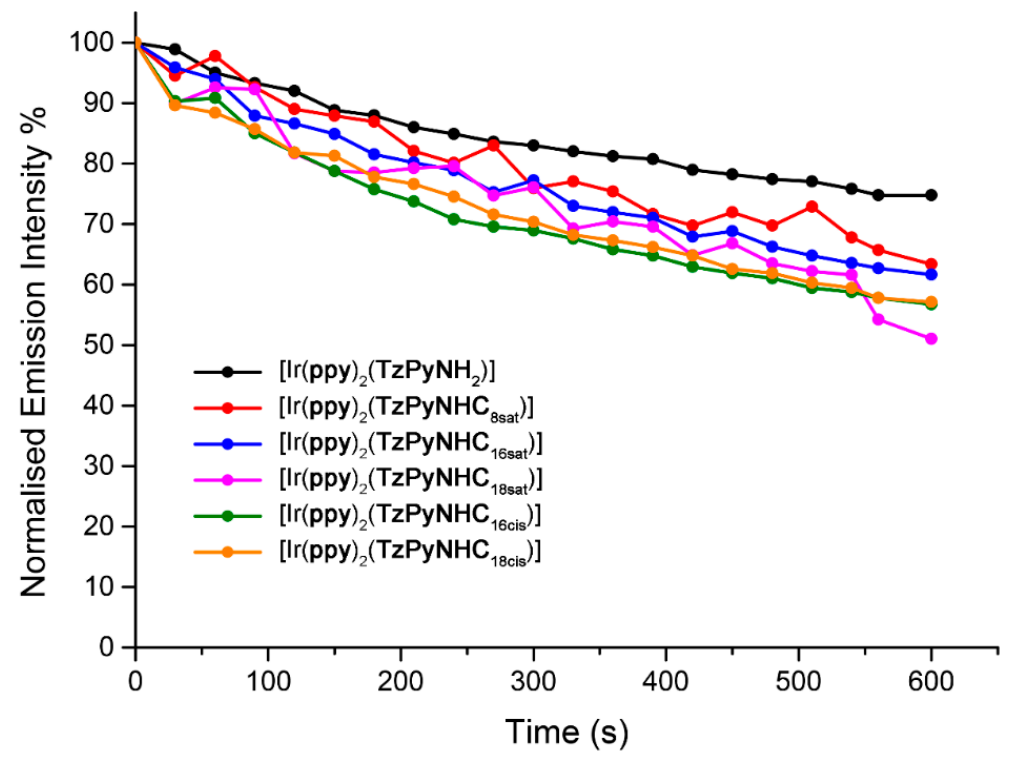

Figure 7. Photobleaching analysis in PBS (2\% DMSO) of the reported iridium complexes.

\section{Materials and Methods}

\subsection{General Considerations}

Unless otherwise stated, all reagents and solvents were purchased from Sigma Aldrich or Alfa Aesar and used as received without further purification. The species $\left[\operatorname{Ir}(\mathbf{p p y})_{2}(\mu-\mathrm{Cl})\right]_{2}$ was prepared according to a previously published procedure [59]. The acyl chloride of the fatty acids was obtained by heating the corresponding acid in $5 \mathrm{~mL}$ of thionyl chloride, which was used as solvent, and removing the solvent under reduced pressure after $3 \mathrm{~h}$ [26-28]. Nuclear magnetic resonance spectra were recorded using a Bruker Avance 400 spectrometer $\left(400 \mathrm{MHz}\right.$ for ${ }^{1} \mathrm{H} \mathrm{NMR} ; 100 \mathrm{MHz}$ for ${ }^{13} \mathrm{C}$ NMR) at $300 \mathrm{~K}$. All NMR spectra were calibrated to residual solvent signals. Infrared spectra were recorded using an attenuated total reflectance Perkin Elmer Spectrum 100 FT-IR with a diamond stage. IR spectra were recorded from 4000 to $650 \mathrm{~cm}^{-1}$. The intensity of the band is reported as strong (s), medium (m), or weak (w), with broad (br) bands also specified. Melting points were determined using a BI Barnsted Electrotermal 9100 apparatus. Elemental analyses were carried out on bulk samples using a Thermo Finning EA 1112 Series Flash; the presence of solvents was further confirmed by ${ }^{1} \mathrm{H}$ NMR. Chromatographic separation was achieved with a Thermo Fisher Ultimate 3000 UHPLC system coupled to an Hypersil C18 column $100 \times 2.1 \mathrm{~mm}, 1.9 \mu \mathrm{m}$ using acetonitrile and water containing $0.1 \%$ formic acid as mobile phases at $0.3 \mathrm{~mL} / \mathrm{min}$ flow rate. Organic compounds were analysed using a Q Exactive ${ }^{\mathrm{TM}}$ Focus Hybrid Quadrupole-Orbitrap ${ }^{\mathrm{TM}}$ Mass Spectrometer from Thermo Fisher (Thermo Fisher Scientific Corporation, US). Analytes ionisation was achieved using a heated electrospray ionisation source (HESI) operated in positive mode. The Q Exactive mass spectrometer was operated in full-scan mode from 130 to $2000 \mathrm{~m} / \mathrm{z}$ followed by isolation and full MS2 fragmentation of the parent compound in the HDC cell at variable collision energy. Data was processed using Xcalibur QualBrowser. Lysosomal fluid solution was prepared following previously published procedures [60].

\subsection{Photophysical Measurements}

Absorption spectra were recorded at room temperature using a Cary $4000 \mathrm{UV} /$ Vis spectrometer. Uncorrected steady state emission and excitation spectra were recorded on an Edinburgh 
FLSP980-S2S2-stm spectrometer equipped with: (i) a temperature-monitored cuvette holder; (ii) 450 W Xenon arc lamp; (iii) double excitation and emission monochromators; and (iv) a Peltier cooled Hamamatsu R928P photomultiplier tube (spectral range 200-870 nm). Emission and excitation spectra were corrected for source intensity (lamp and grating) and emission spectral response (detector and grating) by a calibration curve supplied with the instrument. According to the approach described by Demas and Crosby [61], luminescence quantum yields $(\Phi)$ were measured in optically dilute solutions (O.D. < 0.1 at excitation wavelength) obtained from absorption spectra on a wavelength scale [nm] and compared to the reference emitter by Equation (1):

$$
\Phi_{x}=\Phi_{r}\left[\frac{A_{r}\left(\lambda_{r}\right)}{A_{x}\left(\lambda_{x}\right)} \frac{I_{r}\left(\lambda_{r}\right)}{I_{x}\left(\lambda_{x}\right)} \frac{n_{x}^{2}}{n_{r}^{2}} \frac{D_{x}}{D_{r}}\right]
$$

where $A$ is the absorbance at the excitation wavelength $(\lambda), I$ is the intensity of the excitation light at the excitation wavelength $(\lambda), n$ is the refractive index of the solvent, $D$ is the integrated intensity of the luminescence, and $\Phi$ is the quantum yield. The subscripts $r$ and $x$ refer to the reference and the sample, respectively. The quantum yield determinations were performed at an identical excitation wavelength for the sample and the reference, therefore cancelling the $I\left(\lambda_{r}\right) / I\left(\lambda_{x}\right)$ term in the equation. The quantum yields of complexes were measured against an aqueous solution of $\left[\mathrm{Ru}(\mathbf{b i p y})_{3}\right] \mathrm{Cl}_{2}(\mathbf{b i p y}$ $=2,2^{\prime}$-bipyridine; $\Phi_{r}=0.028$ ) [29]. Emission lifetimes $(\tau)$ were determined with the time-correlated single photon counting technique (TCSPC) with the same Edinburgh FLSP980-S2S2-stm spectrometer using a pulsed picosecond LED (EPLED/EPL $377 \mathrm{~nm}$, FHWM $<800 \mathrm{ps}$ ). The goodness of fit was assessed by minimising the reduced $\chi^{2}$ function and by visual inspection of the weighted residuals. The solvents used for the preparation of the solutions for the photophysical investigations were of LR grade, and the water was deionised. Degassing of the dichloromethane solutions was performed using the freeze-pump-thaw method. Experimental uncertainties are estimated to be $\pm 8 \%$ for lifetime determinations, $\pm 20 \%$ for quantum yields, and $\pm 2 \mathrm{~nm}$ and $\pm 5 \mathrm{~nm}$ for absorption and emission peaks, respectively.

\subsection{Temperature-Dependent Emission Lifetimes}

Temperature-dependent emission lifetimes were measured using the previously described Edinburgh FLSP980-S2S2-stm spectrometer using a pulsed picosecond LED (EPLED/EPL $377 \mathrm{~nm}$, FHWM < $800 \mathrm{ps}$ ) and an Optistat DN2 nitrogen cryostat 77 K (temperature range: 77-300 K, temperature stability: $\pm 0.1 \mathrm{~K})$. The concentration of the sample solutions was ca. $1 \times 10^{-5} \mathrm{M}$. The temperature was varied from 198 to $298 \mathrm{~K}$ using dichloromethane as a solvent.

\subsection{Lipophilicity}

Log $D_{7.4}$ values were determined by applying the shake-flask method developed by Kunz et al. [40]. Equal volumes of phosphate-buffered saline solution (PBS) and n-octanol were stirred together for $72 \mathrm{~h}$ prior to use to allow saturation of both the phases. For each experiment, $500 \mu \mathrm{L}$ of PBS, $530 \mu \mathrm{L}$ of $n$-octanol, and $30 \mu \mathrm{L}$ of the complex solution $(2 \mathrm{mg}$ of the analysed species dissolved in $200 \mu \mathrm{L}$ of DMSO) were combined in an Eppendorf tube and stirred for $30 \mathrm{~min}$, follow by centrifugation (5 min, $3000 \mathrm{rpm}$ ) to separate the two phases. The UV/Vis absorption of each phase was recorded at $400 \mathrm{~nm}$. Samples were diluted with the corresponding phase prior to measurement in case the absorption was exceeding 1. Values of $\log \mathrm{D}_{7.4}$ were calculated following Equation (2):

$$
\log D_{7.4}=\log \left[\frac{\left(A_{\text {octanol }(400 \mathrm{~nm})} \cdot f_{\text {octanol }}\right)}{\left(A_{\text {PBS }(400 \mathrm{~nm})} \cdot f_{\text {PBS }}\right)}\right]
$$


where $A_{\text {octanol(400nm) }}$ and $A_{P B S(400 \mathrm{~nm})}$ are the absorbance in each phase at $400 \mathrm{~nm}$ and $f_{\text {octanol }}$ and $f_{P B S}$ are the dilution factors. The given values and standard deviations were derived from three independent experiments.

\subsection{Cell Staining}

HeLa cells were maintained in RPMI-1640 culture medium (Sigma-Aldrich) supplemented with $10 \%$ FBS (fetal bovine serum) at $37{ }^{\circ} \mathrm{C}$ and $5 \% \mathrm{CO}_{2}$. The HeLa cells were cultured in $75 \mathrm{~mm}^{2}$ flasks and passaged at $90 \%$ confluence; no more than 18 passages were performed for the cells used in the experiments. For live cell imaging, HeLa cells were cultured overnight in $250 \mu \mathrm{L}$ of FBS-free RPMI-1640 culture medium in ibidi $\mu$-slide 8 wells with a seeding density of $1 \times 10^{5}$ cells $/ \mathrm{mL}$. After 12 to $24 \mathrm{~h}$, HeLa cells were incubated with the Ir complexes at a concentration of $5 \mu \mathrm{M}$ in FBS-free RPMI-1640 culture medium with 2\% DMSO (Sigma-Aldrich), for $20 \mathrm{~min}$ at $37^{\circ} \mathrm{C}$ and $5 \% \mathrm{CO}_{2}$. The cells were washed twice with sterile phosphate-buffered saline solution (PBS; Sigma-Aldrich, St. Louis, MO, USA) before imaging in RPMI-1640 culture medium.

\subsection{Cell Viability}

HEK293-T cells were seeded into a 96-well plate and cultured in complete DMEM medium. The following day, cells were incubated with each Ir complex (final concentrations of $20 \mu \mathrm{M}$ and $40 \mu \mathrm{M}, 4 \times$ repeats) for $2 \mathrm{~h}$ and $24 \mathrm{~h}$, alongside the culture media controls. Alamar blue solution was prepared as a $100 \times$ fresh stock of Resazurin $5 \mathrm{mg} / \mathrm{mL}$, which was (purchased from Sigma Aldrich) in PBS solution. To assess cell viability, the cells were then incubated with fresh media containing Alamar blue at $50 \mu \mathrm{g} / \mathrm{mL}$ for a further $1-2 \mathrm{~h}$ at $37^{\circ} \mathrm{C}$. During the incubation, Resazurin was reduced into a fluorescent metabolite Resorufin proportionally to the amount of intra-cellular reductases. The amount of Resorufin, a proxy of cell viability, was quantified by fluorescence output at $585 \mathrm{~nm}\left(\lambda_{\mathrm{exc}}=570 \mathrm{~nm}\right)$, and an averaged value for repeats reported as a percentage of the controls [62-64].

\subsection{Photobleaching}

Three $\mathrm{mL}$ of a diluted (ca. $10^{-5} \mathrm{M}$ ) PBS solution (2\% DMSO) of each Ir complex was irradiated continuously for $600 \mathrm{~s}$ with a frame rate of $30 \mathrm{~s}$. The irradiation source was a Pen-Ray ${ }^{\circledR}$ Mercury Lamp $\left(\lambda_{\text {exc }}=365 \mathrm{~nm}, 5 \mathrm{~mW}\right)$, which was located $3 \mathrm{~cm}$ from the sample. The emission spectra were recorded on an Edinburgh FLSP980-S2S2-stm spectrometer.

\subsection{Confocal Microscopy}

Single photon live cell imaging was performed using a Nikon A1+ confocal microscope equipped with a A1-DUS spectral detector unit (Nikon, Japan) and an OKOLab Microscope Incubator (Okolab USA Inc., State Abbr., USA). The Ir complexes were excited at $403 \mathrm{~nm}$ and the emission was collected in the 400-750 $\mathrm{nm}$ region using the spectral detector. Image analysis was performed using NIS elements V4.50 software (Version, Nikon, Japan). The final preparation of the images was conducted with Adobe Photoshop CC (Adobe Systems Inc., State Abbr., USA).

\subsection{Synthesis}

For the NMR characterisation, the protons and carbons of all the $\operatorname{Ir}(\mathrm{III})$ tetrazolato complexes were assigned as pyridinic (A), phenylic (B), tetrazolic (T), and aliphatic (F), according to Scheme 1. 


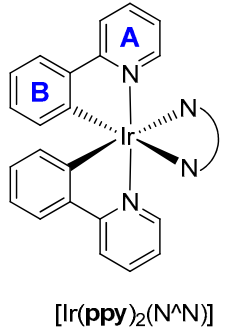

$\left[\operatorname{lr}(\mathbf{p p y})_{2}\left(\mathrm{~N}^{\wedge} \mathrm{N}\right)\right]$
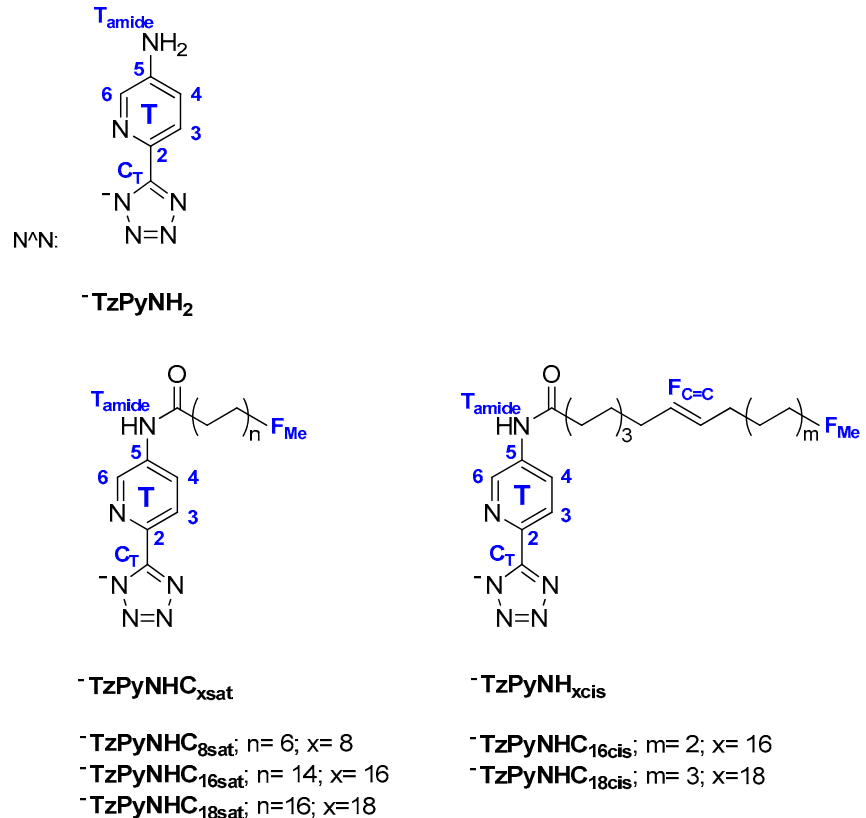

Scheme 1. Numbering system used to identify specific $\mathrm{H}$ and $\mathrm{C}$ atoms associated to their corresponding peaks in the NMR spectra.

$\mathbf{H T z P y N H}_{2}$. Triethylamine $(2.1 \mathrm{~mL}, 0.015 \mathrm{~mol})$ was added to toluene $(15 \mathrm{~mL})$, and the solution was cooled to $0{ }^{\circ} \mathrm{C}$. $\mathrm{HCl} 32 \%(1.3 \mathrm{~mL}, 0.015 \mathrm{~mol})$ was added to the reaction mixture and stirred until fuming subsided. Then, 5-amino-2-pyridinecarbonitrile $(0.500 \mathrm{~g}, 0.004 \mathrm{~mol})$ and sodium azide (1.090 g, 0.017 mol) were added and heated at reflux overnight. After cooling down to room temperature, the mixture was extracted with water $(2 \times 15 \mathrm{~mL})$, and the aqueous phase was collected and acidified to $\mathrm{pH} \approx 3$ with $\mathrm{HCl} 32 \%$. An orange-pink precipitate formed, which was then filtered and dried in air. Yield: $0.280 \mathrm{~g}$ (41\%). M.P. $270-272{ }^{\circ} \mathrm{C}$. IR ( $\left./ \mathrm{cm}^{-1}\right)$ : $3334 \mathrm{~b}(\mathrm{~N}-\mathrm{H}$ stretch), $3160 \mathrm{br}(\mathrm{N}-\mathrm{H}$ strech), $1661 \mathrm{w}(\mathrm{N}-\mathrm{H}$ bend), $1612 \mathrm{w}$ (tetrazole $\mathrm{C}=\mathrm{N}) .{ }^{1} \mathrm{H}$ NMR $\left(\delta / \mathrm{ppm}, \mathrm{DMSO}-d_{6}\right): 8.07\left(\mathrm{~s}, 1 \mathrm{H}, \mathbf{H}_{\mathrm{T} 6}\right), 7.86\left(\mathrm{~d}, 1 \mathrm{H}, \mathbf{H}_{\mathrm{T} 4}, J=8.5 \mathrm{~Hz}\right)$, $7.08\left(\mathrm{~d}, 1 \mathrm{H}, \mathbf{H}_{\mathrm{T} 3}, J=8.5 \mathrm{~Hz}\right), 6.04$ (broad s, 2H, 2H $\left.\mathbf{H}_{\text {Tamine }}\right) .{ }^{13} \mathrm{C}$ NMR $\left(\delta / p p m\right.$, DMSO- $\left.d_{6}\right): 154.9\left(\mathbf{C}_{\mathrm{T}}\right)$, $147.1\left(\mathbf{C}_{\mathbf{T} 2}\right), 135.9\left(\mathbf{C H}_{\mathbf{T} 6}\right), 130.4\left(\mathbf{C}_{\mathbf{T} 5}\right), 123.4\left(\mathrm{CH}_{\mathbf{T} 4}\right), 119.7\left(\mathrm{CH}_{\mathbf{T} 3}\right)$. ESI-HRMS $(\mathrm{m} / z)$ : Theoretical [M + $\mathrm{H}]^{+}=163.0725 \mathrm{~m} / \mathrm{z}$; Found $[\mathrm{M}+\mathrm{H}]^{+}=163.0727 \mathrm{~m} / \mathrm{z}$. Anal. Calcd for HTzPyNH $2 \cdot 0.5($ water): C, 42.10; H, 4.12; N, 49.10. Found: C, 42.10; H, 4.07; N, 48.95 .

$\left[\operatorname{Ir}(\mathbf{p p y})_{2}\left(\mathrm{TzPyNH}_{2}\right)\right]$. [ $\left.\operatorname{Ir}(\mathbf{p p y})_{2}(\mu-\mathrm{Cl})\right]_{2}(0.285 \mathrm{~g}, 0.266 \mathrm{mmol})$ was combined with $\mathrm{HTzPyNH}_{2}$ $(0.108 \mathrm{~g}, 0.666 \mathrm{mmol})$ and dissolved in $13 \mathrm{~mL}$ of a dichloromethane/ethanol mixture $(10: 3 \mathrm{v} / \mathrm{v})$. Triethylamine (10 drops) was added, and the resulting suspension was stirred at room temperature overnight. The product was precipitated with diethyl ether as a yellow solid, filtered, and dried in air. Yield: $0.200 \mathrm{~g}$ (57\%). M.P. > $400{ }^{\circ} \mathrm{C}(\mathrm{dec}) . \mathrm{IR}\left(\mathrm{v} / \mathrm{cm}^{-1}\right): 3307 \mathrm{~b}(\mathrm{~N}-\mathrm{H}$ stretch), $3163 \mathrm{br}(\mathrm{N}-\mathrm{H}$ stretch), $1641 \mathrm{w}(\mathrm{N}-\mathrm{H}$ bend), $1605 \mathrm{w}$ (tetrazole $\mathrm{C}=\mathrm{N}) .{ }^{1} \mathrm{H}$ NMR $\left(\delta / \mathrm{ppm}, \mathrm{DMSO}-d_{6}\right): 8.18$ (app. t., $2 \mathrm{H}, \mathbf{H}_{\mathrm{T} 4}, \mathbf{H}_{\mathrm{T} 3}$, splitting $=8.7 \mathrm{~Hz}), 7.95\left(\mathrm{~d}, 1 \mathrm{H}, \mathbf{H}_{\mathrm{T} 6}, J=8.6 \mathrm{~Hz}\right), 7.90-7.86\left(\mathrm{~m}, 3 \mathrm{H}, 3 \mathbf{H}_{\mathrm{A}}\right), 7.78\left(\mathrm{~d}, 1 \mathrm{H}, \mathbf{H}_{\mathbf{B}}, J=8.0 \mathrm{~Hz}\right)$, $7.63\left(\mathrm{~d}, 1 \mathrm{H}, \mathbf{H}_{\mathrm{A}}, J=5.6 \mathrm{~Hz}\right), 7.21-7.15\left(\mathrm{~m}, 3 \mathrm{H}, 3 \mathbf{H}_{\mathbf{A}}\right), 7.11\left(\mathrm{~s}, 1 \mathrm{H}, \mathbf{H}_{\mathbf{B}}\right), 6.96$ (app. t., 1H, $\mathbf{H}_{\mathbf{B}}, \mathrm{splitting}=$ $7.5 \mathrm{~Hz}$ ), 6.90-6.83 (m, 2H, 2H $\left.\mathbf{H}_{\mathbf{B}}\right), 6.74$ (app. t., $1 \mathrm{H}, \mathbf{H}_{\mathbf{B}}$, splitting = 7.4 Hz), $6.21\left(\mathrm{~d}, 1 \mathrm{H}, \mathbf{H}_{\mathbf{B}}, J=7.5 \mathrm{~Hz}\right)$, $6.15\left(\mathrm{~d}, 1 \mathrm{H}, \mathbf{H}_{\mathbf{B}}, J=7.5 \mathrm{~Hz}\right), 6.01$ (broad s, 2H, 2H Tamine). ${ }^{13} \mathrm{C}$ NMR $\left(\delta / p p m\right.$, DMSO- $\left.d_{6}\right): 167.5\left(\mathbf{C}_{\mathbf{T}}\right)$, $167.4\left(\mathbf{C}_{\mathbf{T} 2}\right), 163.9\left(\mathbf{C}_{\mathbf{T} 5}\right), 152.7\left(\mathbf{C}_{\mathbf{A}}\right), 148.7\left(\mathbf{C H}_{\mathbf{A}}\right), 148.3\left(\mathbf{C H}_{\mathbf{A}}\right), 148.2\left(\mathbf{C H}_{\mathbf{A}}\right), 147.5\left(\mathbf{C}_{\mathbf{A}}\right), 144.3\left(\mathbf{C}_{\mathbf{B}}\right), 144.0$ $\left(\mathbf{C}_{\mathbf{B}}\right), 138.1\left(\mathbf{C H}_{\mathbf{A}}\right), 137.7\left(\mathbf{C H}_{\mathbf{A}}\right), 135.6\left(\mathbf{C}_{\mathbf{B}}\right), 135.2\left(\mathbf{C H}_{\mathbf{B}}\right), 131.4\left(\mathbf{C H}_{\mathbf{B}}\right), 131.2\left(\mathbf{C H}_{\mathbf{B}}\right), 129.9\left(\mathbf{C H}_{\mathbf{B}}\right), 129.0$ $\left(\mathbf{C H}_{\mathbf{B}}\right), 124.7\left(\mathbf{C H}_{\mathbf{A}}\right), 124.2\left(\mathbf{C H}_{\mathbf{B}}\right), 123.3\left(\mathbf{2 H}_{\mathbf{A}}\right), 123.0\left(\mathbf{C H}_{\mathbf{T}}\right), 122.2\left(\mathbf{C}_{\mathbf{B}}\right), 121.6\left(\mathbf{C H}_{\mathbf{B}}\right), 120.9\left(\mathbf{C H}_{\mathbf{B}}\right)$, $119.5\left(\mathrm{CH}_{\mathbf{T} 4}\right), 119.3\left(\mathrm{CH}_{\mathrm{T} 3}\right)$. ESI-HRMS $(\mathrm{m} / \mathrm{z})$ : Theoretical $[\mathrm{M}+\mathrm{H}]^{+}=661.1568 \mathrm{~m} / \mathrm{z}$; Found $[\mathrm{M}+\mathrm{H}]^{+}=$ $661.1567 \mathrm{~m} / \mathrm{z}$. Anal. Calcd for $\left[\operatorname{Ir}(\mathbf{p p y})_{2}\left(\mathrm{TzPyNH}_{2}\right)\right] \cdot 0.2\left(\mathrm{CH}_{2} \mathrm{Cl}_{2}\right): \mathrm{C}, 49.90 ; \mathrm{H}, 3.18 ; \mathrm{N}, 16.51$. Found: C, $49.91 ; \mathrm{H}, 3.21 ; \mathrm{N}, 16.54$. 
[Ir(ppy) $\mathbf{2}_{\mathbf{2}}$ (TzPyNHC $\left.\left._{8 s a t}\right)\right]$. [Ir(ppy $\left.)_{2}\left(\mathbf{T z P y N H}_{2}\right)\right](0.100 \mathrm{~g}, 0.152 \mathrm{mmol})$ and triethylamine $(0.32 \mathrm{~mL}$, $2.270 \mathrm{mmol})$ were combined in $10 \mathrm{~mL}$ of dry dichloromethane. Octanoyl chloride $(0.26 \mathrm{~mL}, 1.520 \mathrm{mmol})$ was dissolved in $3 \mathrm{~mL}$ of dry dichloromethane, added dropwise to the reaction mixture, and stirred at room temperature overnight. The solution was concentrated, and diethyl ether was added. A white precipitate was formed and filtered. The filtrate was washed with $\mathrm{NaHCO}_{3} 5 \%$ solution $(3 \times 15 \mathrm{~mL})$. The organic phase was dried over $\mathrm{MgSO}_{4}$ anhydrous, and the product was purified via column chromatography using Brockmann I grade basic alumina filled as the stationary phase and a dichloromethane/methanol (99.5:0.5 v/v) solvent system mixture as eluent. The targeted complex eluted as the second fraction (yellow), the solvent was removed under reduced pressure, and the product was isolated as a yellow solid. Yield: $0.091 \mathrm{~g}(76 \%)$. M.P. $252-254{ }^{\circ} \mathrm{C}$. IR $\left(\mathrm{v} / \mathrm{cm}^{-1}\right): 2924 \mathrm{~s}$, $2853 \mathrm{~s}(\mathrm{CH}$ stretch saturated $\mathrm{C}-\mathrm{C}), 1699 \mathrm{w}(\mathrm{C}=\mathrm{O}$ functionalised stretch), $1606 \mathrm{w}$ (tetrazole $\mathrm{C}=\mathrm{N}) .{ }^{1} \mathrm{H}$ NMR ( $\delta / p p m$, DMSO- $\left.d_{6}\right): 10.31\left(\mathrm{~s}, 1 \mathrm{H}, \mathbf{H}_{\text {Tamide }}\right), 8.34\left(\mathrm{~d}, 1 \mathrm{H}, \mathbf{H}_{\mathrm{T} 4}, J=8.7 \mathrm{~Hz}\right), 8.27\left(\mathrm{~d}, 1 \mathrm{H}, \mathbf{H}_{\mathrm{T} 3}, J=8.8\right.$ $\mathrm{Hz}), 8.20-8.17\left(\mathrm{~m}, 2 \mathrm{H}, 2 \mathrm{H}_{\mathrm{A}}\right), 8.14\left(\mathrm{~s}, 1 \mathrm{H}, \mathbf{H}_{\mathrm{T} 6}\right), 7.89-7.84\left(\mathrm{~m}, 3 \mathrm{H}, 3 \mathrm{H}_{\mathrm{A}}\right), 7.79\left(\mathrm{~d}, 1 \mathrm{H}, \mathbf{H}_{\mathbf{B}}, \mathrm{J}=7.7 \mathrm{~Hz}\right)$, $7.62\left(\mathrm{~d}, 1 \mathrm{H}, \mathbf{H}_{\mathbf{B}}, J=5.6 \mathrm{~Hz}\right), 7.39\left(\mathrm{~d}, 1 \mathrm{H}, \mathbf{H}_{\mathbf{B}}, J=5.6 \mathrm{~Hz}\right), 7.18-7.11\left(\mathrm{~m}, 2 \mathrm{H}, 2 \mathrm{H}_{\mathrm{A}}\right), 6.97($ app. $t ., 1 \mathrm{H}$, $\mathbf{H}_{\mathbf{A}}$, splitting $\left.=7.4 \mathrm{~Hz}\right), 6.91-6.84\left(\mathrm{~m}, 2 \mathrm{H}, 2 \mathbf{H}_{\mathbf{B}}\right), 6.75$ (app. t., $1 \mathrm{H}, \mathbf{H}_{\mathrm{A}}$, splitting $\left.=7.4 \mathrm{~Hz}\right), 6.21(\mathrm{~d}, 1 \mathrm{H}$, $\left.\mathbf{H}_{\mathrm{B}}, \mathrm{J}=7.5 \mathrm{~Hz}\right), 6.13\left(\mathrm{~d}, 1 \mathrm{H}, \mathbf{H}_{\mathrm{B}}, J=7.5 \mathrm{~Hz}\right), 2.23\left(\mathrm{t}, 2 \mathrm{H}, 2 \mathrm{H}_{\mathrm{F}}, J=7.5 \mathrm{~Hz}\right), 1.52-1.45\left(\mathrm{~m}, 2 \mathrm{H}, 2 \mathrm{H}_{\mathrm{F}}\right), 1.22$ (broad s, 24H, 24H $\left.\mathrm{H}_{\mathrm{F}}\right), 0.84\left(\mathrm{t}, 3 \mathrm{H}, 3 \mathrm{H}_{\mathrm{FMe}}, J=7.2 \mathrm{~Hz}\right) .{ }^{13} \mathrm{C}$ NMR $\left(\delta / \mathrm{ppm}, \mathrm{DMSO}-d_{6}\right): 172.0(\mathrm{CO}), 167.4$ $\left(\mathbf{C}_{\mathbf{T}}\right), 167.3\left(\mathrm{C}_{\mathrm{T} 2}\right), 163.4\left(\mathrm{C}_{\mathbf{A}}\right), 151.6\left(\mathrm{C}_{\mathbf{B}}\right), 148.7\left(2 \mathrm{CH}_{\mathbf{B}}\right), 147.4\left(\mathrm{C}_{\mathbf{B}}\right), 144.2\left(\mathrm{C}_{\mathbf{B}}\right), 144.0\left(\mathrm{C}_{\mathbf{B}}\right), 142.5\left(\mathrm{C}_{\mathrm{T} 5}\right)$, $140.8\left(\mathrm{CH}_{\mathbf{T} 6}\right), 138.3\left(\mathrm{CH}_{\mathbf{A}}\right), 138.2\left(\mathrm{CH}_{\mathbf{A}}\right), 137.9\left(\mathbf{C}_{\mathbf{A}}\right), 131.3\left(2 \mathrm{CH}_{\mathbf{B}}\right), 129.9\left(\mathrm{CH}_{\mathbf{B}}\right), 129.1\left(\mathbf{C H}_{\mathbf{B}}\right), 128.8$ $\left(\mathrm{CH}_{\mathrm{T} 4}\right), 124.8\left(\mathrm{CH}_{\mathbf{A}}\right), 124.2\left(\mathrm{CH}_{\mathbf{B}}\right), 123.4\left(\mathrm{CH}_{\mathbf{A}}\right), 123.3\left(\mathrm{CH}_{\mathbf{A}}\right), 121.8\left(\mathrm{CH}_{\mathbf{A}}\right), 121.1\left(\mathrm{CH}_{\mathbf{B}}\right), 119.6\left(\mathrm{CH}_{\mathbf{A}}\right)$, 119.4 $\left(\mathrm{CH}_{\mathbf{A}}\right), 36.1\left(\mathrm{CH}_{\mathbf{F}}\right), 31.1\left(\mathrm{CH}_{\mathbf{F}}\right), 28.5\left(\mathrm{CH}_{\mathbf{F}}\right), 28.4\left(\mathrm{CH}_{\mathbf{F}}\right), 24.7\left(\mathrm{CH}_{\mathbf{F}}\right), 22.0\left(\mathrm{CH}_{\mathbf{F}}\right), 13.9\left(\mathrm{CH}_{\mathbf{F M e}}\right)$. ESI-HRMS $(\mathrm{m} / \mathrm{z})$ : Theoretical $[\mathrm{M}+\mathrm{H}]^{+}=787.2613 \mathrm{~m} / \mathrm{z}$; Found $[\mathrm{M}+\mathrm{H}]^{+}=787.2611 \mathrm{~m} / \mathrm{z}$. Anal. Calcd for $\left[\operatorname{Ir}(\mathbf{p p y})_{2}\left(\right.\right.$ TzPyNHC $\left.\left._{8 \text { sat }}\right)\right]:$ C, 54.88; H, 4.48; N, 14.22. Found: C, 54.83; H, 4.53; N, 14.18.

$\left[\operatorname{Ir}(\text { ppy })_{2}\right.$ (TzPyNHC $\left.\left._{16 s a t}\right)\right] .\left[\operatorname{Ir}(\mathbf{p p y})_{2}\left(\mathbf{T z P y N H}_{2}\right)\right](0.100 \mathrm{~g}, 0.152 \mathrm{mmol})$ and triethylamine $(0.32 \mathrm{~mL}$, $2.270 \mathrm{mmol}$ ) were combined in $10 \mathrm{~mL}$ of dry dichloromethane. Palmitoyl chloride $(0.46 \mathrm{~mL}, 1.520 \mathrm{mmol})$ was dissolved in $3 \mathrm{~mL}$ of dry dichloromethane, added dropwise to the reaction mixture, and stirred at room temperature overnight. The solution was concentrated, and diethyl ether was added. A white precipitate was formed and filtered. The filtrate was washed with $\mathrm{NaHCO}_{3} 5 \%$ solution $(3 \times 15 \mathrm{~mL})$. The organic phase was dried over $\mathrm{MgSO}_{4}$ anhydrous, and the product was purified via column chromatography using Brockmann I grade basic alumina filled as the stationary phase and a dichloromethane/methanol (99.5:0.5 v/v) solvent system mixture as eluent. The targeted complex eluted as the second fraction (yellow), the solvent was removed under reduced pressure, and the product isolated as a yellow solid. Yield: $0.107 \mathrm{~g}(78 \%)$. M.P. $321-314{ }^{\circ} \mathrm{C}$. IR $\left(\mathrm{v} / \mathrm{cm}^{-1}\right): 2923 \mathrm{~s}, 2849 \mathrm{~s}$ ( $\mathrm{CH}$ stretch saturated $\mathrm{C}-\mathrm{C}), 1703 \mathrm{w}(\mathrm{C}=\mathrm{O}$ functionalised stretch), $1607 \mathrm{w}$ (tetrazole $\mathrm{C}=\mathrm{N}) .{ }^{1} \mathrm{H}$ NMR ( $\delta /$ ppm, DMSO- $\left.d_{6}\right): 10.31\left(\mathrm{~s}, 1 \mathrm{H}, \mathbf{H}_{\text {Tamide }}\right), 8.33\left(\mathrm{~d}, 1 \mathrm{H}, \mathbf{H}_{\mathrm{T} 4}, \mathrm{~J}=8.8 \mathrm{~Hz}\right), 8.27\left(\mathrm{~d}, 1 \mathrm{H}, \mathbf{H}_{\mathrm{T} 3}, \mathrm{~J}=8.7 \mathrm{~Hz}\right)$, $8.20-8.17\left(\mathrm{~m}, 2 \mathrm{H}, 2 \mathbf{H}_{\mathrm{A}}\right), 8.14\left(\mathrm{~s}, 1 \mathrm{H}, \mathbf{H}_{\mathrm{T} 6}\right), 7.89-7.83\left(\mathrm{~m}, 3 \mathrm{H}, 3 \mathbf{H}_{\mathrm{A}}\right), 7.79\left(\mathrm{~d}, 1 \mathrm{H}, \mathbf{H}_{\mathrm{B}}, \mathrm{J}=7.9 \mathrm{~Hz}\right), 7.62(\mathrm{~d}$, $\left.1 \mathrm{H}, \mathbf{H}_{\mathbf{B}}, J=5.2 \mathrm{~Hz}\right), 7.39\left(\mathrm{~d}, 1 \mathrm{H}, \mathbf{H}_{\mathbf{B}}, J=5.2 \mathrm{~Hz}\right), 7.17-7.11\left(\mathrm{~m}, 2 \mathrm{H}, \mathbf{2} \mathbf{H}_{\mathbf{A}}\right), 6.97$ (app. t., $1 \mathrm{H}, \mathbf{H}_{\mathbf{A}}$, splitting $=7.5 \mathrm{~Hz}), 6.91-6.84\left(\mathrm{~m}, 2 \mathrm{H}, 2 \mathbf{H}_{\mathbf{B}}\right), 6.75$ (app. t., $1 \mathrm{H}, \mathbf{H}_{\mathbf{A}}$, splitting = $\left.7.4 \mathrm{~Hz}\right), 6.21\left(\mathrm{~d}, 1 \mathrm{H}, \mathbf{H}_{\mathbf{B}}, J=8.8 \mathrm{~Hz}\right.$ ), $6.13\left(\mathrm{~d}, 1 \mathrm{H}, \mathrm{H}_{\mathrm{B}}, J=8.8 \mathrm{~Hz}\right), 2.22\left(\mathrm{t}, 2 \mathrm{H}, 2 \mathrm{H}_{\mathrm{F}}, J=7.5 \mathrm{~Hz}\right), 1.49-1.43\left(\mathrm{~m}, 2 \mathrm{H}, 2 \mathrm{H}_{\mathrm{F}}\right), 1.22$ (broad s., $24 \mathrm{H}$, $\left.24 \mathrm{H}_{\mathrm{F}}\right), 0.84\left(\mathrm{t}, 3 \mathrm{H}, 3 \mathrm{H}_{\mathrm{FMe}}, J=6.8 \mathrm{~Hz}\right) .{ }^{13} \mathrm{C} \mathrm{NMR}\left(\delta / \mathrm{ppm}, \mathrm{DMSO}-d_{6}\right): 172.0(\mathrm{CO}), 167.4\left(\mathrm{C}_{\mathrm{T}}\right), 167.3\left(\mathrm{C}_{\mathrm{T} 2}\right)$, $163.5\left(\mathbf{C}_{\mathbf{A}}\right), 151.7\left(\mathbf{C}_{\mathbf{B}}\right), 148.7\left(2 \mathrm{CH}_{\mathbf{B}}\right), 147.4\left(\mathbf{C}_{\mathbf{B}}\right), 144.2\left(\mathbf{C}_{\mathbf{B}}\right), 144.0\left(\mathbf{C}_{\mathbf{B}}\right), 142.5\left(\mathbf{C}_{\mathbf{T} 5}\right), 140.8\left(\mathrm{CH}_{\mathbf{T} 6}\right), 138.3$ $\left(\mathrm{CH}_{\mathbf{A}}\right), 138.2\left(\mathrm{CH}_{\mathbf{A}}\right), 137.9\left(\mathbf{C}_{\mathbf{A}}\right), 131.3\left(2 \mathrm{CH}_{\mathbf{B}}\right), 129.9\left(\mathrm{CH}_{\mathbf{B}}\right), 129.1\left(\mathbf{C H}_{\mathbf{B}}\right), 128.8\left(\mathrm{CH}_{\mathbf{T} 4}\right), 124.8\left(\mathrm{CH}_{\mathbf{A}}\right)$, $124.3\left(\mathrm{CH}_{\mathbf{B}}\right), 123.4\left(\mathrm{CH}_{\mathbf{A}}\right), 123.3\left(\mathrm{CH}_{\mathbf{A}}\right), 122.6\left(\mathrm{CH}_{\mathrm{T} 3}\right), 121.9\left(\mathrm{CH}_{\mathbf{A}}\right), 121.1\left(\mathrm{CH}_{\mathbf{B}}\right), 119.6\left(\mathrm{CH}_{\mathbf{A}}\right), 119.4$ $\left(\mathrm{CH}_{\mathrm{A}}\right), 36.1\left(\mathrm{CH}_{\mathrm{F}}\right), 31.3\left(2 \mathrm{CH}_{\mathrm{F}}\right), 29.0\left(2 \mathrm{CH}_{\mathrm{F}}\right), 28.9\left(2 \mathrm{CH}_{\mathrm{F}}\right), 28.8\left(\mathrm{CH}_{\mathrm{F}}\right), 28.7\left(2 \mathrm{CH}_{\mathrm{F}}\right), 28.6\left(\mathrm{CH}_{\mathrm{F}}\right), 24.7$ $\left(\mathrm{CH}_{\mathbf{F}}\right), 22.1\left(2 \mathrm{CH}_{\mathbf{F}}\right), 14.0\left(\mathrm{CH}_{\mathbf{F M e}}\right)$. ESI-HRMS $(\mathrm{m} / \mathrm{z})$ : Theoretical $[\mathrm{M}+\mathrm{H}]^{+}=899.3865 \mathrm{~m} / \mathrm{z}$; Found $[\mathrm{M}+$ $\mathrm{H}^{+}=899.3864 \mathrm{~m} / \mathrm{z}$. Anal. Calcd for $\left[\operatorname{Ir}(\text { ppy })_{2}(\right.$ TzPyNHC 16 sat $\left.)\right] \cdot 0.5\left(\mathrm{CH}_{2} \mathrm{Cl}_{2}\right): \mathrm{C}, 56.70 ; \mathrm{H}, 5.56 ; \mathrm{N}, 11.89$. Found: C, 56.70; H, 5.60; N, 11.87 .

$\left[\operatorname{Ir}(\text { ppy })_{2}\right.$ (TzPyNHC $\left.\left._{18 s a t}\right)\right] .\left[\operatorname{Ir}(\mathbf{p p y})_{2}\left(\mathrm{TzPyNH}_{2}\right)\right](0.100 \mathrm{~g}, 0.152 \mathrm{mmol})$ and triethylamine $(0.32 \mathrm{~mL}$, $2.270 \mathrm{mmol}$ ) were combined in $10 \mathrm{~mL}$ of dry dichloromethane. Stearoyl chloride $(0.51 \mathrm{~mL}, 1.520$ $\mathrm{mmol}$ ) was dissolved in $3 \mathrm{~mL}$ of dry dichloromethane, added dropwise to the reaction mixture, and 
stirred at room temperature overnight. The solution was concentrated, and diethyl ether was added. A white precipitate was formed and filtered. The filtrate was washed with $\mathrm{NaHCO}_{3} 5 \%$ solution $(3 \times 15 \mathrm{~mL})$. The organic phase was dried over $\mathrm{MgSO}_{4}$ anhydrous, and the product was purified via column chromatography using a Brockmann I grade basic alumina-filled as the stationary phase and a dichloromethane/methanol $(99.5: 0.5 \mathrm{v} / \mathrm{v})$ solvent system mixture as eluent. The targeted complex eluted as the second fraction (yellow), the solvent was removed under reduced pressure, and the product was isolated as a yellow solid. Yield: $0.097 \mathrm{~g}(69 \%)$. M.P. $308-310^{\circ} \mathrm{C}$. IR (v/cm $\left.{ }^{-1}\right): 2922 \mathrm{~s}, 2849 \mathrm{~s}$ (CH stretch saturated $\mathrm{C}-\mathrm{C}), 1703 \mathrm{w}$ (C=O functionalised stretch), $1607 \mathrm{w}$ (tetrazole $\mathrm{C}=\mathrm{N}) .{ }^{1} \mathrm{H}$ NMR

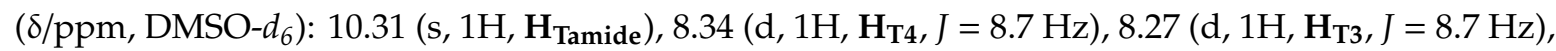
8.22-8.17 (m, 2H, 2H $\left.\mathbf{H}_{\mathrm{A}}\right), 8.14\left(\mathrm{~s}, 1 \mathrm{H}, \mathbf{H}_{\mathrm{T} 6}\right), 7.91-7.82\left(\mathrm{~m}, 3 \mathrm{H}, 3 \mathbf{H}_{\mathbf{A}}\right), 7.79\left(\mathrm{~d}, 1 \mathrm{H}, \mathbf{H}_{\mathbf{B}}, J=8.9 \mathrm{~Hz}\right), 7.62(\mathrm{~d}$, $\left.1 \mathrm{H}, \mathbf{H}_{\mathbf{B}}, J=7.2 \mathrm{~Hz}\right), 7.39\left(\mathrm{~d}, 1 \mathrm{H}, \mathbf{H}_{\mathbf{B}}, J=7.2 \mathrm{~Hz}\right), 7.18-7.10\left(\mathrm{~m}, 2 \mathrm{H}, 2 \mathbf{H}_{\mathbf{A}}\right), 6.97$ (app. t., 1H, $\mathbf{H}_{\mathbf{A}}$, splitting $=8.1 \mathrm{~Hz}), 6.91-6.84\left(\mathrm{~m}, 2 \mathrm{H}, 2 \mathbf{H}_{\mathbf{B}}\right), 6.75$ (app. t., $1 \mathrm{H}, \mathbf{H}_{\mathrm{A}}$, splitting $\left.=8.1 \mathrm{~Hz}\right), 6.21\left(\mathrm{~d}, 1 \mathrm{H}, \mathbf{H}_{\mathbf{B}}, J=7.5\right.$ $\mathrm{Hz}), 6.13\left(\mathrm{~d}, 1 \mathrm{H}, \mathbf{H}_{\mathbf{B}}, J=7.5 \mathrm{~Hz}\right), 2.22\left(\mathrm{t}, 2 \mathrm{H}, 2 \mathrm{H}_{\mathrm{F}}, J=7.2 \mathrm{~Hz}\right), 1.51-1.44\left(\mathrm{~m}, 2 \mathrm{H}, 2 \mathrm{H}_{\mathrm{F}}\right), 1.22$ (broad s., $\left.28 \mathrm{H}, \mathbf{2 8 H _ { F }}\right), 0.83\left(\mathrm{t}, 3 \mathrm{H}, 3 \mathrm{H}_{\mathrm{FMe}}, J=6.4 \mathrm{~Hz}\right) .{ }^{13} \mathrm{C}$ NMR $\left(\delta / \mathrm{ppm}, \mathrm{DMSO}-d_{6}\right): 172.0(\mathrm{CO}), 167.4\left(\mathbf{C}_{\mathrm{T}}\right), 167.3$ $\left(\mathbf{C}_{\mathbf{T} 2}\right), 163.5\left(\mathbf{C}_{\mathbf{A}}\right), 151.7\left(\mathbf{C}_{\mathbf{A}}\right), 148.7\left(2 \mathbf{C H}_{\mathbf{B}}\right), 147.4\left(\mathbf{C}_{\mathbf{B}}\right), 144.2\left(\mathbf{C}_{\mathbf{B}}\right), 144.0\left(\mathbf{C}_{\mathbf{B}}\right), 142.5\left(\mathbf{C}_{\mathbf{T} 5}\right), 140.8\left(\mathbf{C H}_{\mathbf{T 6}}\right)$, $138.3\left(\mathbf{2 C H}_{\mathbf{A}}\right), 137.9\left(\mathbf{C}_{\mathbf{B}}\right), 131.3\left(2 \mathbf{C H}_{\mathbf{B}}\right), 130.0\left(\mathbf{C H}_{\mathbf{B}}\right), 129.1\left(\mathbf{C H}_{\mathbf{T} 4}\right), 128.8\left(\mathbf{C H}_{\mathbf{B}}\right), 124.8\left(2 \mathbf{C H}_{\mathbf{A}}\right), 124.3$ $\left(\mathbf{C H}_{\mathbf{B}}\right), 123.4\left(\mathbf{C H}_{\mathbf{A}}\right), 122.6\left(\mathbf{C H}_{\mathbf{T} 3}\right), 121.9\left(\mathbf{C H}_{\mathbf{A}}\right), 121.1\left(\mathbf{C H}_{\mathbf{B}}\right), 119.6\left(\mathbf{C H}_{\mathbf{A}}\right), 119.4\left(\mathbf{C H}_{\mathbf{A}}\right), 36.2\left(\mathbf{C H}_{\mathbf{F}}\right)$, $31.3\left(\mathbf{C H}_{\mathbf{F}}\right), 30.7\left(\mathbf{2} \mathrm{CH}_{\mathbf{F}}\right), 29.0\left(3 \mathrm{CH}_{\mathbf{F}}\right), 28.9\left(\mathbf{2} \mathrm{CH}_{\mathbf{F}}\right), 28.8\left(\mathbf{C H}_{\mathbf{F}}\right), 28.7\left(\mathbf{2} \mathrm{CH}_{\mathbf{F}}\right), 28.6\left(\mathbf{C H}_{\mathbf{F}}\right), 28.5\left(\mathbf{C H}_{\mathbf{F}}\right), 24.7$ $\left(\mathrm{CH}_{\mathbf{F}}\right), 22.1\left(\mathrm{CH}_{\mathbf{F}}\right), 14.0\left(\mathrm{CH}_{\mathbf{F M e}}\right)$. ESI-HRMS $(\mathrm{m} / \mathrm{z})$ : Theoretical $[\mathrm{M}+\mathrm{H}]^{+}=927.4178 \mathrm{~m} / \mathrm{z}$; Found $[\mathrm{M}+$ $\mathrm{H}^{+}=927.4179 \mathrm{~m} / \mathrm{z}$. Anal. Calcd for $\left[\operatorname{Ir}(\mathbf{p p y})_{2}\left(\mathrm{TzPyNHC}_{\mathbf{1 8 s a t}}\right)\right] \cdot 0.5\left(\mathrm{CH}_{3} \mathrm{OH}\right): \mathrm{C}, 59.15 ; \mathrm{H}, 6.08 ; \mathrm{N}, 11.87$. Found: C, 59.16; H, 5.96; N, 11.81 .

$\left.\left[\operatorname{Ir}(\mathbf{p p y})_{\mathbf{2}} \mathbf{( T z P y N H C}_{\mathbf{1 6} \text { cis }}\right)\right]$. [ $\left.\operatorname{Ir}(\mathbf{p p y})_{\mathbf{2}}\left(\mathbf{T z P y N H}_{\mathbf{2}}\right)\right](0.100 \mathrm{~g}, 0.152 \mathrm{mmol})$ and triethylamine $(0.32 \mathrm{~mL}$, $2.270 \mathrm{mmol})$ were combined in $10 \mathrm{~mL}$ of dry dichloromethane. Palmitoleoyl chloride $(0.46 \mathrm{~mL}$, $1.520 \mathrm{mmol}$ ) was dissolved in $3 \mathrm{~mL}$ of dry dichloromethane, added dropwise to the reaction mixture, and stirred at room temperature overnight. The solution was concentrated, and diethyl ether was added. A white precipitate was formed and filtered. The filtrate was washed with $\mathrm{NaHCO}_{3} 5 \%$ solution $(3 \times 15 \mathrm{~mL})$. The organic phase was dried over $\mathrm{MgSO}_{4}$ anhydrous, and the product was purified via column chromatography using a Brockmann I grade basic alumina filled as the stationary phase and a dichloromethane/methanol (99.5:0.5 v/v) solvent system mixture as eluent. The targeted complex eluted as the second fraction (yellow), the solvent was removed under reduced pressure, and the product was isolated as a yellow solid. Yield: $0.085 \mathrm{~g}(62 \%)$. M.P. $194-196^{\circ} \mathrm{C}$. IR (v/cm $\left.{ }^{-1}\right): 3006$ w (=C-H stretch), $2922 \mathrm{~s}, 2851 \mathrm{~s}$ (CH stretch saturated C-C), $1703 \mathrm{w}$ (C=O functionalised stretch), 1607 w (tetrazole $\mathrm{C}=\mathrm{N}) .{ }^{1} \mathrm{H}$ NMR $\left(\delta / \mathrm{ppm}, \mathrm{DMSO}-d_{6}\right): 10.31\left(\mathrm{~s}, 1 \mathrm{H}, \mathbf{H}_{\text {Tamide }}\right), 8.34\left(\mathrm{~d}, 1 \mathrm{H}, \mathbf{H}_{\mathrm{T} 4}, J=8.8 \mathrm{~Hz}\right)$, $8.27\left(\mathrm{~d}, 1 \mathrm{H}, \mathbf{H}_{\mathrm{T} 3}, J=8.7 \mathrm{~Hz}\right), 8.20-8.19\left(\mathrm{~m}, 2 \mathrm{H}, \mathbf{2} \mathbf{H}_{\mathrm{A}}\right), 8.13\left(\mathrm{~s}, 1 \mathrm{H}, \mathbf{H}_{\mathrm{T} 6}\right), 7.89-7.83\left(\mathrm{~m}, 3 \mathrm{H}, 3 \mathbf{H}_{\mathrm{A}}\right), 7.79(\mathrm{~d}$, $\left.1 \mathrm{H}, \mathbf{H}_{\mathbf{B}}, J=7.9 \mathrm{~Hz}\right), 7.62\left(\mathrm{~d}, 1 \mathrm{H}, \mathbf{H}_{\mathbf{B}}, J=5.2 \mathrm{~Hz}\right), 7.39\left(\mathrm{~d}, 1 \mathrm{H}, \mathbf{H}_{\mathbf{B}}, J=5.2 \mathrm{~Hz}\right), 7.18-7.10\left(\mathrm{~m}, 2 \mathrm{H}, 2 \mathbf{H}_{\mathbf{A}}\right)$, 6.97 (app. t., $1 \mathrm{H}, \mathbf{H}_{\mathrm{A}}$, splitting $\left.=7.5 \mathrm{~Hz}\right), 6.91-6.84\left(\mathrm{~m}, 2 \mathrm{H}, \mathbf{2} \mathbf{H}_{\mathbf{B}}\right), 6.75$ (app. t., $1 \mathrm{H}, \mathbf{H}_{\mathrm{A}}$, splitting $=7.4$ $\mathrm{Hz}), 6.21\left(\mathrm{~d}, 1 \mathrm{H}, \mathbf{H}_{\mathbf{B}}, J=8.8 \mathrm{~Hz}\right), 6.13\left(\mathrm{~d}, 1 \mathrm{H}, \mathbf{H}_{\mathbf{B}}, \mathrm{J}=8.8 \mathrm{~Hz}\right), 5.32-5.30\left(\mathrm{~m}, 2 \mathrm{H}, 2 \mathbf{H}_{\mathrm{FCH}=\mathrm{CH}}\right), 2.22(\mathrm{t}, 2 \mathrm{H}$, 2H $\left.\mathbf{H}_{\mathrm{F}}, J=7.5 \mathrm{~Hz}\right), 1.99-1.94\left(\mathrm{~m}, 3 \mathrm{H}, 3 \mathbf{H}_{\mathrm{F}}\right), 1.51-1.46\left(\mathrm{~m}, 2 \mathrm{H}, \mathbf{2} \mathbf{H}_{\mathrm{F}}\right), 1.23$ (broad s., 15H, 15H $\left.\mathbf{H}_{\mathrm{F}}\right), 0.85-0.80$ $\left(\mathrm{m}, 3 \mathrm{H}, 3 \mathrm{H}_{\mathrm{FMe}}\right) .{ }^{13} \mathrm{C}$ NMR $\left(\delta / \mathrm{ppm}, \mathrm{DMSO}-d_{6}\right): 172.0(\mathrm{CO}), 167.4\left(\mathbf{C}_{\mathbf{T}}\right), 167.3\left(\mathbf{C}_{\mathbf{T} 2}\right), 163.5\left(\mathbf{C}_{\mathbf{A}}\right), 151.7$ $\left(\mathbf{C}_{\mathbf{B}}\right), 148.7\left(2 \mathrm{CH}_{\mathbf{B}}\right), 147.4\left(\mathbf{C}_{\mathbf{B}}\right), 144.3\left(\mathbf{C}_{\mathbf{B}}\right), 144.0\left(\mathbf{C}_{\mathbf{B}}\right), 142.5\left(\mathbf{C}_{\mathbf{T} 5}\right), 140.8\left(\mathbf{C H}_{\mathbf{T} 6}\right), 138.4\left(\mathbf{C H}_{\mathbf{A}}\right), 138.3$ $\left(\mathbf{C H}_{\mathbf{A}}\right), 137.9\left(\mathbf{C}_{\mathbf{A}}\right), 131.3\left(\mathbf{C H}_{\mathbf{B}}\right), 130.0\left(\mathbf{C H}_{\mathbf{B}}\right), 129.7\left(\mathbf{C H}_{\mathbf{F C H}}=\mathbf{C H}\right), 129.6\left(\mathbf{C H}_{\mathbf{F C H}}=\mathbf{C H}\right), 129.1\left(\mathbf{C H}_{\mathbf{B}}\right)$, $128.9\left(\mathrm{CH}_{\mathbf{T} 4}\right), 124.8\left(\mathrm{CH}_{\mathbf{A}}\right), 124.3\left(\mathrm{CH}_{\mathbf{B}}\right), 123.4\left(\mathrm{CH}_{\mathbf{A}}\right), 123.3\left(\mathrm{CH}_{\mathbf{A}}\right), 122.6\left(\mathrm{CH}_{\mathbf{T} 3}\right), 121.9\left(\mathrm{CH}_{\mathbf{A}}\right), 121.1$ $\left(\mathrm{CH}_{\mathbf{B}}\right), 119.6\left(\mathrm{CH}_{\mathbf{A}}\right), 119.4\left(\mathrm{CH}_{\mathbf{A}}\right), 36.2\left(\mathrm{CH}_{\mathbf{F}}\right), 31.1\left(2 \mathrm{CH}_{\mathbf{F}}\right), 29.1\left(\mathrm{CH}_{\mathbf{F}}\right), 28.6\left(2 \mathrm{CH}_{\mathbf{F}}\right), 28.5\left(\mathrm{CH}_{\mathbf{F}}\right), 28.2$ $\left(\mathrm{CH}_{\mathbf{F}}\right), 26.6\left(\mathrm{CH}_{\mathbf{F}}\right), 24.7\left(\mathrm{CH}_{\mathbf{F}}\right), 22.1\left(2 \mathrm{CH}_{\mathbf{F}}\right), 13.9\left(\mathrm{CH}_{\mathbf{F M e}}\right)$. ESI-HRMS $(\mathrm{m} / \mathrm{z})$ : Theoretical $[\mathrm{M}+\mathrm{H}]^{+}=$ $897.3708 \mathrm{~m} / \mathrm{z}$; Found $[\mathrm{M}+\mathrm{H}]^{+}=897.3710 \mathrm{~m} / \mathrm{z}$. Anal. Calcd for [Ir(ppy) $\left.2\left(\mathrm{TzPyNHC}_{16 \text { cis }}\right)\right]: \mathrm{C}, 58.84 ; \mathrm{H}$, 5.50; N, 12.48. Found: C, 59.04; H, 5.55; N, 12.27 .

[Ir(ppy) $\mathbf{2}_{\mathbf{2}}$ TzPyNHC $\left.\left._{\mathbf{1 8 c i s}}\right)\right]$. [Ir(ppy $\left.)_{2}\left(\mathbf{T z P y N H}_{\mathbf{2}}\right)\right](0.100 \mathrm{~g}, 0.152 \mathrm{mmol})$ and triethylamine $(0.32 \mathrm{~mL}$, $2.270 \mathrm{mmol})$ were combined in $10 \mathrm{~mL}$ of dry dichloromethane. Oleoyl chloride $(0.50 \mathrm{~mL}, 1.520 \mathrm{mmol})$ was dissolved in $3 \mathrm{~mL}$ of dry dichloromethane, added dropwise to the reaction mixture, and stirred at room temperature overnight. The solution was concentrated, and diethyl ether was added. A 
white precipitate was formed and filtered. The filtrate was washed with $\mathrm{NaHCO}_{3} 5 \%$ solution $(3 \times 15 \mathrm{~mL})$. The organic phase was dried over $\mathrm{MgSO}_{4}$ anhydrous, and the product was purified via column chromatography using a Brockmann I grade basic alumina filled as stationary phase and a dichloromethane/methanol (99.5:0.5 $v / v)$ solvent system mixture as eluent. The targeted complex eluted as the second fraction (yellow), the solvent was removed under reduced pressure, and the product was isolated as a yellow solid. Yield: $0.085 \mathrm{~g}(61 \%)$. M.P. $186-189^{\circ} \mathrm{C}$. IR $\left(v / \mathrm{cm}^{-1}\right): 3004 \mathrm{w}(=\mathrm{C}-\mathrm{H}$ stretch), $2922 \mathrm{~s}, 2852 \mathrm{~s}(\mathrm{CH}$ stretch saturated $\mathrm{C}-\mathrm{C}), 1700 \mathrm{w}(\mathrm{C}=\mathrm{O}$ functionalised stretch), $1606 \mathrm{w}$ (tetrazole $\mathrm{C}=\mathrm{N}$ ). ${ }^{1} \mathrm{H}$ NMR ( $\delta / \mathrm{ppm}$, DMSO- $\left.d_{6}\right): 10.31\left(\mathrm{~s}, 1 \mathrm{H}, \mathbf{H}_{\text {Tamide }}\right), 8.35\left(\mathrm{~d}, 1 \mathrm{H}, \mathbf{H}_{\mathrm{T} 4}, J=8.8 \mathrm{~Hz}\right), 8.27\left(\mathrm{~d}, 1 \mathrm{H}, \mathbf{H}_{\mathrm{T} 3}, J=\right.$ $8.7 \mathrm{~Hz}), 8.19-8.17\left(\mathrm{~m}, 2 \mathrm{H}, 2 \mathbf{H}_{\mathrm{A}}\right), 8.13\left(\mathrm{~s}, 1 \mathrm{H}, \mathbf{H}_{\mathrm{T} 6}\right), 7.89-7.83\left(\mathrm{~m}, 3 \mathrm{H}, 3 \mathbf{H}_{\mathrm{A}}\right), 7.79\left(\mathrm{~d}, 1 \mathrm{H}, \mathbf{H}_{\mathbf{B}}, J=7.9 \mathrm{~Hz}\right)$, $7.62\left(\mathrm{~d}, 1 \mathrm{H}, \mathbf{H}_{\mathbf{B}}, J=5.2 \mathrm{~Hz}\right), 7.39\left(\mathrm{~d}, 1 \mathrm{H}, \mathbf{H}_{\mathbf{B}}, J=5.2 \mathrm{~Hz}\right), 7.18-7.10\left(\mathrm{~m}, 2 \mathrm{H}, 2 \mathbf{H}_{\mathrm{A}}\right), 6.96\left(\right.$ app. t., $1 \mathrm{H}, \mathbf{H}_{\mathrm{A}}$, splitting = $8.0 \mathrm{~Hz}), 6.91-6.84\left(\mathrm{~m}, 2 \mathrm{H}, 2 \mathbf{H}_{\mathbf{B}}\right), 6.75\left(\right.$ app. t., $1 \mathrm{H}, \mathbf{H}_{\mathrm{A}}$, splitting $\left.=8.0 \mathrm{~Hz}\right), 6.21\left(\mathrm{~d}, 1 \mathrm{H}, \mathbf{H}_{\mathbf{B}}, J=\right.$ $8.8 \mathrm{~Hz}), 6.13\left(\mathrm{~d}, 1 \mathrm{H}, \mathbf{H}_{\mathbf{B}}, J=8.8 \mathrm{~Hz}\right), 5.32-5.30\left(\mathrm{~m}, 2 \mathrm{H}, 2 \mathrm{H}_{\mathrm{FCH}}=\mathrm{CH}\right), 2.22\left(\mathrm{t}, 2 \mathrm{H}, 2 \mathrm{H}_{\mathrm{F}}, J=7.5 \mathrm{~Hz}\right), 1.99-1.94$ $\left(\mathrm{m}, 4 \mathrm{H}, 4 \mathrm{H}_{\mathrm{F}}\right), 1.51-1.46\left(\mathrm{~m}, 2 \mathrm{H}, 2 \mathrm{H}_{\mathrm{F}}\right), 1.18$ (broad s, 20H, 20H $), 0.83-0.80\left(\mathrm{~m}, 3 \mathrm{H}, 3 \mathrm{H}_{\mathrm{FMe}}\right) .{ }^{13} \mathrm{C} \mathrm{NMR}$

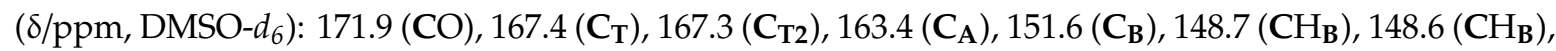
147.4 $\left(\mathbf{C}_{\mathbf{B}}\right), 144.2\left(\mathbf{C}_{\mathbf{B}}\right), 144.0\left(\mathbf{C}_{\mathbf{B}}\right), 142.5\left(\mathrm{C}_{\mathrm{T} 5}\right), 140.8\left(\mathrm{CH}_{\mathrm{T} 6}\right), 138.3\left(\mathrm{CH}_{\mathbf{A}}\right), 138.2\left(\mathrm{CH}_{\mathbf{A}}\right), 137.9\left(\mathbf{C}_{\mathbf{A}}\right)$, $131.3\left(2 \mathrm{CH}_{\mathbf{B}}\right), 129.9\left(\mathrm{CH}_{\mathbf{A}}\right), 129.6\left(\mathrm{CH}_{\mathrm{FCH}=\mathrm{CH}}\right), 129.5\left(\mathrm{CH}_{\mathrm{FCH}}=\mathrm{CH}\right), 129.0\left(\mathrm{CH}_{\mathbf{B}}\right), 128.8\left(\mathrm{CH}_{\mathrm{T} 4}\right), 124.8$ $\left(\mathbf{C H}_{\mathbf{B}}\right), 124.2\left(\mathbf{C H}_{\mathbf{B}}\right), 123.3\left(\mathrm{CH}_{\mathbf{A}}\right), 123.2\left(\mathrm{CH}_{\mathbf{A}}\right), 122.5\left(\mathrm{CH}_{\mathbf{T} 3}\right), 121.8\left(\mathrm{CH}_{\mathbf{A}}\right), 121.1\left(\mathrm{CH}_{\mathbf{B}}\right), 119.6\left(\mathrm{CH}_{\mathbf{A}}\right)$, $119.4\left(\mathrm{CH}_{\mathbf{A}}\right), 36.1\left(\mathrm{CH}_{\mathbf{F}}\right), 31.2\left(\mathrm{CH}_{\mathbf{F}}\right), 29.1\left(\mathrm{CH}_{\mathbf{F}}\right), 29.0\left(\mathrm{CH}_{\mathbf{F}}\right), 28.8\left(\mathrm{CH}_{\mathbf{F}}\right), 28.6\left(2 \mathrm{CH}_{\mathbf{F}}\right), 28.5\left(2 \mathrm{CH}_{\mathbf{F}}\right), 28.4$ $\left(\mathrm{CH}_{\mathrm{F}}\right), 26.5\left(2 \mathrm{CH}_{\mathrm{F}}\right), 24.7\left(\mathrm{CH}_{\mathrm{F}}\right), 22.0\left(\mathrm{CH}_{\mathrm{F}}\right), 13.9\left(\mathrm{CH}_{\mathrm{FMe}}\right)$. ESI-HRMS $(\mathrm{m} / \mathrm{z})$ : Theoretical $[\mathrm{M}+\mathrm{H}]^{+}=$ $925.4021 \mathrm{~m} / z$; Found $[\mathrm{M}+\mathrm{H}]^{+}=925.4018 \mathrm{~m} / z$. Anal. Calcd for $\left[\operatorname{Ir}(\mathbf{p p y})_{2}\left(\right.\right.$ TzPyNHC $\left.\left._{18 \mathrm{zcis}}\right)\right] \cdot 0.3\left(\mathrm{CH}_{3} \mathrm{OH}\right)$ : C, 59.40; H; 5.85; N, 11.96. Found: C, 59.49; H, 5.85; N, 12.00 .

\section{Conclusions}

This work reports the synthesis of a family of cyclometallated neutral Ir(III) tetrazolato complexes functionalised with fatty acid chains of variable length and saturation. The fatty acids have been grafted onto the precursor complex $\left[\operatorname{Ir}(\mathbf{p p y})_{2}\left(\mathrm{TzPyNH}_{2}\right)\right]$ by the formation of a secondary amide bond. The photophysical properties reveals a green-yellow phosphorescent emission for all the complexes that was derived from a mixture of ${ }^{3} \mathrm{MLCT}$ and ${ }^{3} \mathrm{LC}$ excited states, which was comparable to the one recorded for the precursor $\left[\operatorname{Ir}(\mathbf{p p y})_{2}\left(\mathbf{T z P y N H}_{2}\right)\right]$. Temperature-dependent lifetime measurements on $\left[\operatorname{Ir}(\mathbf{p p y})_{2}\left(\mathrm{TzPyNHC}_{16 \mathrm{cis}}\right)\right]$ have suggested that the excited states might be partially quenched via thermally activated higher-lying dark states. Aside from $\left[\operatorname{Ir}(\mathbf{p p y})_{2}\left(\operatorname{TzPyNHC}_{\mathbf{1 6 s a t}}\right)\right]$ and $\left[\operatorname{Ir}(\mathbf{p p y})_{2}\left(\mathrm{TzPyNHC}_{18 \mathrm{sat}}\right)\right]$, the complexes were internalised within live HeLa cells at a concentration of $5 \mu \mathrm{M}$. The staining pattern suggests localisation within the endoplasmic reticulum, which is a feature that has been previously observed for neutral metal complexes. However, further investigation will be needed to assess whether the newly prepared iridium complexes display some selectivity for specific classes of lipids. Compared to the previously investigated iridium tetrazolato complexes, the fatty acids appended species do not seem to show distribution between the endoplasmic reticulum and the lipids droplets. The cytotoxicity assay showed good cellular viability $(\geq 85 \%)$ at high concentration and for long incubation times for all of the complexes. Moreover, the length of the chains or the degree of unsaturation of the appended fatty acids does not affect the toxicity of the complexes. These derivatives, along with few $\mathrm{Pt}(\mathrm{II})$ species, are also some of the few reported examples of complexes functionalised with fatty acids or long alkyl chains, which show low cytotoxicity. Finally, high photostability in the cuvette has been recorded for the whole series of Ir(III) complexes. Minor structural modifications to overcome the solubility issues, particularly for the long chain fatty acid conjugates, would produce a scaffold for the synthesis of other fatty acid-functionalised analogues.

Supplementary Materials: The following are available online at http://www.mdpi.com/2304-6740/8/4/23/s1, NMR spectra for the complexes; photophysical data and spectra; emission profiles from stained cells.

Author Contributions: Conceptualization, M.M., C.C., A.M.R. and S.P.; Investigation, C.C., A.M.R., S.E.P. and C.A.B.; Methodology, C.A.B.; Supervision, M.M., M.F., S.E.P. and D.A.B.; Validation, M.M., S.E.P., D.A.B. and S.S.; 
Writing—original draft, C.C.; Writing—review \& editing, M.M. All authors have read and agreed to the published version of the manuscript.

Funding: This research received no external funding.

Acknowledgments: Chiara Caporale, Anna Maria Ranieri and Silvano Paternoster wish to thank Curtin University for their PhD scholarship.

Conflicts of Interest: The authors declare no conflict of interest. Iridium complexes of a similar chemical structure are commercially available as cellular markers by ReZolve Scientific. Massimiliano Massi, Sally Plush, Stefano Stagni, and Douglas Brooks are shareholders of ReZolve Scientific. The company had no role in the design of the study; in the collection, analyses, or interpretation of data; in the writing of the manuscript, and in the decision to publish the results.

\section{References}

1. Kolanowski, J.L.; Liu, F.; New, E.J. Fluorescent probes for the simultaneous detection of multiple analytes in biology. Chem. Soc. Rev. 2018, 47, 195-208. [CrossRef] [PubMed]

2. Kaur, A.; Kolanowski, J.L.; New, E.J. Reversible Fluorescent Probes for Biological Redox States. Angew. Chem. Int. Ed. 2016, 55, 1602-1613. [CrossRef]

3. Depaoli, M.R.; Bischof, H.; Eroglu, E.; Burgstaller, S.; Ramadani-Muja, J.; Rauter, T.; Schinagl, M.; Waldeck-Weiermair, M.; Hay, J.C.; Graier, W.F.; et al. Live cell imaging of signaling and metabolic activities. Pharmacol. Ther. 2019, 202, 98-119. [CrossRef] [PubMed]

4. Samanta, S.; He, Y.; Sharma, A.; Kim, J.; Pan, W.H.; Yang, Z.G.; Li, J.; Yan, W.; Liu, L.W.; Qu, J.L.; et al. Fluorescent Probes for Nanoscopic Imaging of Mitochondria. Chem 2019, 5, 1697-1726. [CrossRef]

5. Fernandez-Moreira, V.; Thorp-Greenwood, F.L.; Coogan, M.P. Application of $\mathrm{d}^{6}$ transition metal complexes in fluorescence cell imaging. Chem. Commun. 2010, 46, 186-202. [CrossRef] [PubMed]

6. Lo, K.K.W. Luminescent Rhenium(I) and Iridium(III) Polypyridine Complexes as Biological Probes, Imaging Reagents, and Photocytotoxic Agents. Acc. Chem. Res. 2015, 48, 2985-2995. [CrossRef] [PubMed]

7. Heffern, M.C.; Matosziuk, L.M.; Meade, T.J. Lanthanide Probes for Bioresponsive Imaging. Chem. Rev. 2014, 114, 4496-4539. [CrossRef] [PubMed]

8. Coogan, M.P.; Fernandez-Moreira, V. Progress with, and prospects for, metal complexes in cell imaging. Chem. Commun. 2014, 50, 384-399. [CrossRef] [PubMed]

9. Barnard, P.J.; Wedlock, L.E.; Baker, M.V.; Berners-Price, S.J.; Joyce, D.A.; Skelton, B.W.; Steer, J.H. Luminescence studies of the intracellular distribution of a dinuclear gold(I) $N$-heterocyclic carbene complex. Angew. Chem. Int. Ed. 2006, 45, 5966-5970. [CrossRef]

10. Botchway, S.W.; Charnley, M.; Haycock, J.W.; Parker, A.W.; Rochester, D.L.; Weinstein, J.A.; Williams, J.A.G. Time-resolved and two-photon emission imaging microscopy of live cells with inert platinum complexes. Proc. Natl. Acad. Sci. USA 2008, 105, 16071-16076. [CrossRef]

11. Mauro, M.; Aliprandi, A.; Septiadi, D.; Kehra, N.S.; De Cola, L. When self-assembly meets biology: Luminescent platinum complexes for imaging applications. Chem. Soc. Rev. 2014, 43, 4144-4166. [CrossRef] [PubMed]

12. New, E.J.; Congreve, A.; Parker, D. Definition of the uptake mechanism and sub-cellular localisation profile of emissive lanthanide complexes as cellular optical probes. Chem. Sci. 2010, 1, 111-118. [CrossRef]

13. Lee, L.C.C.; Leung, K.K.; Lo, K.K.W. Recent development of luminescent rhenium(I) tricarbonyl polypyridine complexes as cellular imaging reagents, anticancer drugs, and antibacterial agents. Dalton Trans. 2017, 46, 16357-16380. [CrossRef] [PubMed]

14. Jarman, P.J.; Noakes, F.; Fairbanks, S.; Smitten, K.; Griffiths, I.K.; Saeed, H.K.; Thomas, J.A.; Smythe, C. Exploring the Cytotoxicity, Uptake, Cellular Response, and Proteomics of Mono- and Dinuclear DNA Light-Switch Complexes. J. Am. Chem. Soc. 2019, 141, 2925-2937. [CrossRef]

15. Pettinari, R.; Marchetti, F.; Pettinari, C.; Condello, F.; Petrini, A.; Scopelliti, R.; Riedel, T.; Dyson, P.J. Organometallic rhodium(III) and iridium(III) cyclopentadienyl complexes with curcumin and bisdemethoxycurcumin co-ligands. Dalton Trans. 2015, 44, 20523-20531. [CrossRef]

16. Colombo, A.; Fontani, M.; Dragonetti, C.; Roberto, D.; Williams, J.A.G.; di Perrotolo, R.S.; Casagrande, F.; Barozzi, S.; Polo, S. A Highly Luminescent Tetrahydrocurcumin Ir-III Complex with Remarkable Photoactivated Anticancer Activity. Chem. Eur. J. 2019, 25, 7948-7952. [CrossRef] 
17. Mari, C.; Panigati, M.; D’Alfonso, L.; Zanoni, I.; Donghi, D.; Sironi, L.; Collini, M.; Maiorana, S.; Baldoli, C.; D'Alfonso, G.; et al. Luminescent Conjugates between Dinuclear Rhenium Complexes and Peptide Nucleic Acids (PNA): Synthesis, Photophysical Characterization, and Cell Uptake. Organometallics 2012, 31, 5918-5928. [CrossRef]

18. Ranieri, A.M.; Caporale, C.; Fiorini, V.; Hubbard, A.; Rigby, P.; Stagni, S.; Watkin, E.; Ogden, M.I.; Hackett, M.J.; Massi, M. Complementary Approaches to Imaging Subcellular Lipid Architectures in Live Bacteria Using Phosphorescent Iridium Complexes and Raman Spectroscopy. Chem. Eur. J. 2019, 25, 10566-10570. [CrossRef]

19. Bader, C.A.; Sorvina, A.; Simpson, P.V.; Wright, P.J.; Stagni, S.; Plush, S.E.; Massi, M.; Brooks, D.A. Imaging nuclear, endoplasmic reticulum and plasma membrane events in real time. Febs Lett. 2016, 590, 3051-3060. [CrossRef] [PubMed]

20. Sadowski, M.C.; Mcpherson, S.J.; Rockstroh, A.; Soekmadji, C.; Tevz, G.; Gunter, J.H.; Jeet, V.; Nelson, C.C. Comprehensive profiling of androgen signalling and energy and lipid metabolism highlights heterogeneity of prostate cancer cell lines. Bju Int. 2016, 118, 34.

21. Bader, C.A.; Carter, E.A.; Safitri, A.; Simpson, P.V.; Wright, P.; Stagni, S.; Massi, M.; Lay, P.A.; Brooks, D.A.; Plush, S.E. Unprecedented staining of polar lipids by a luminescent rhenium complex revealed by FTIR microspectroscopy in adipocytes. Mol. Biosyst. 2016, 12, 2064-2068. [CrossRef] [PubMed]

22. Wang, Z.; Gui, C.; Zhao, E.; Wang, J.; Li, X.; Qin, A.; Zhao, Z.; Yu, Z.; Tang, B.Z. Specific Fluorescence Probes for Lipid Droplets Based on Simple AIEgens. ACS Appl. Mater. Interfaces 2016, 8, 10193-10200. [CrossRef] [PubMed]

23. Caporale, C.; Bader, C.A.; Sorvina, A.; MaGee, K.D.M.; Skelton, B.W.; Gillam, T.A.; Wright, P.J.; Raiteri, P.; Stagni, S.; Morrison, J.L.; et al. Investigating Intracellular Localisation and Cytotoxicity Trends for Neutral and Cationic Iridium Tetrazolato Complexes in Live Cells. Chem. Eur. J. 2017, 23, 15666-15679. [CrossRef]

24. Koguro, K.; Oga, T.; Mitsui, S.; Orita, R. Novel Synthesis of 5-Substituted Tetrazoles from Nitriles. Synthesis 1998, 1998, 910-914. [CrossRef]

25. Stagni, S.; Colella, S.; Palazzi, A.; Valenti, G.; Zacchini, S.; Paolucci, F.; Marcaccio, M.; Albuquerque, R.Q.; De Cola, L. Essential role of the ancillary ligand in the color tuning of iridium tetrazolate complexes. Inorg. Chem. 2008, 47, 10509-10521. [CrossRef]

26. Wissner, A.; Grudzinskas, C.V. Reaction of Tert-Butyldimethylsilyl Esters with Oxalyl Chloride-Dimethylformamide: Preparation of Carboxylic Acid Chlorides under Neutral Conditions. J. Org. Chem. 1978, 43, 3972-3974. [CrossRef]

27. Beniwal, M.; Jain, N. Review Article on Vilsmeier Haack Reaction and Its. Eur. J. Biomed. Pharm. Sci. 2015, 2, 1340-1374.

28. Cherney, A.H.; Kadunce, N.T.; Reisman, S.E. Catalytic asymmetric reductive acyl cross-coupling: Synthesis of enantioenriched acyclic $\alpha, \alpha$-disubstituted ketones. J. Am. Chem. Soc. 2013, 135, 7442-7445. [CrossRef]

29. Nakamaru, K. Synthesis, luminescence quantum yields, and lifetimes of trischelated ruthenium(II) mixed-ligand complexes including 3, 3'-dimethyl-2, 2'-bipyridyl. Bull. Chem. Soc. Jpn. 1982, 55, 2697-2705. [CrossRef]

30. Umamahesh, B.; Karthikeyan, N.S.; Sathiyanarayanan, K.I.; Malicka, J.M.; Cocchi, M. Tetrazole iridium(III) complexes as a class of phosphorescent emitters for high-efficiency OLEDs. J. Mater. Chem. C 2016, 4, 10053-10060. [CrossRef]

31. Lamansky, S.; Djurovich, P.; Murphy, D.; Abdel-Razzaq, F.; Lee, H.E.; Adachi, C.; Burrows, P.E.; Forrest, S.R.; Thompson, M.E. Highly phosphorescent bis-cyclometalated iridium complexes: Synthesis, photophysical characterization, and use in organic light emitting diodes. J. Am. Chem. Soc. 2001, 123, 4304-4312. [CrossRef]

32. Flamigni, L.; Barbieri, A.; Sabatini, C.; Ventura, B.; Barigelletti, F. Photochemistry and photophysics of coordination compounds: Iridium. Top. Curr. Chem. 2007, 171, 143-203. [CrossRef]

33. Mauro, M.; De Paoli, G.; Otter, M.; Donghi, D.; D’Alfonso, G.; De Cola, L. Aggregation induced colour change for phosphorescent iridium(III) complex-based anionic surfactants. Dalton Trans. 2011, 40, 12106-12116. [CrossRef]

34. Leung, S.-K.; Liu, H.-W.; Lo, K.K.-W. Functionalization of luminescent cyclometalated iridium(III) polypyridine complexes with a fluorous moiety: Photophysics, protein-binding, bioconjugation, and cellular uptake properties. Chem. Commun. 2011, 47, 10548-10550. [CrossRef] [PubMed]

35. Schweitzer, C.; Schmidt, R. Physical Mechanisms of Generation and Deactivation of Singlet Oxygen. Chem. Rev. 2003, 103, 1685-1757. [CrossRef] [PubMed] 
36. Abdel-shafi, A.A.; Worrall, D.R. Mechanism of the excited singlet and triplet states quenching by molecular oxygen in acetonitrile. J. Photochem. Photobiol. 2005, 172, 170-179. [CrossRef]

37. Caspar, J.V.; Meyer, T.J. Application of the energy gap law to nonradiative, excited-state decay. J. Phys. Chem. 1983, 87, 952-957. [CrossRef]

38. Koike, K.; Okoshi, N.; Hori, H.; Takeuchi, K.; Ishitani, O.; Tsubaki, H.; Clark, I.P.; George, M.W.; Johnson, F.P.A.; Turner, J.J. Mechanism of the photochemical ligand substitution reactions of $f a c-\left[\operatorname{Re}(\mathrm{bPY})(\mathrm{CO})_{3}\left(\mathrm{PR}_{3}\right)\right]^{+}$ complexes and the properties of their triplet ligand-field excited states. J. Am. Chem. Soc. 2002, 124, 11448-11455. [CrossRef]

39. Costa, R.D.; Monti, F.; Accorsi, G.; Barbieri, A.; Bolink, H.J.; Orti, E.; Armaroli, N. Photophysical Properties of Charged Cyclometalated Ir(III) Complexes: A Joint Theoretical and Experimental Study. Inorg. Chem. 2011, 50, 7229-7238. [CrossRef]

40. Huber, W.; Linder, R.; Niesel, J.; Schatzschneider, U.; Spingler, B.; Kunz, P.C. A comparative study of tricarbonylmanganese photoactivatable CO releasing molecules (PhotoCORMs) by using the myoglobin assay and time-resolved IR spectroscopy. Eur. J. Inorg. Chem. 2012, 3140-3146. [CrossRef]

41. He, L.; Li, Y.; Tan, C.-P.; Ye, R.-R.; Chen, M.-H.; Cao, J.-J.; Ji, L.-N.; Mao, Z.-W. Cyclometalated iridium(III) complexes as lysosome-targeted photodynamic anticancer and real-time tracking agents. Chem. Sci. 2015, 6, 5409-5418. [CrossRef] [PubMed]

42. Zhang, K.Y.; Li, S.P.-Y.; Zhu, N.; Or, L.W.-S.; Cheung, M.S.-H.; Lam, Y.-W.; Lo, K.K.-W. Structure, photophysical and electrochemical properties, biomolecular interactions, and intracellular uptake of luminescent cyclometalated iridium(III) dipyridoquinoxaline complexes. Inorg. Chem. 2010, 49, 2530-2540. [CrossRef] [PubMed]

43. Steunenberg, P.; Ruggi, A.; Van Den Berg, N.S.; Buckle, T.; Kuil, J.; Van Leeuwen, F.W.B.; Velders, A.H. Phosphorescence imaging of living cells with amino acid-functionalized tris(2-phenylpyridine)iridium(III) complexes. Inorg. Chem. 2012, 51, 2105-2114. [CrossRef]

44. Law, W.H.-T.; Lee, L.C.-C.; Louie, M.-W.; Liu, H.-W.; Ang, T.W.-H.; Lo, K.K.-W. Phosphorescent cellular probes and uptake indicators derived from cyclometalated iridium(III) bipyridine complexes appended with a glucose or galactose entity. Inorg. Chem. 2013, 52, 13029-13041. [CrossRef] [PubMed]

45. Cao, J.-J.; Tan, C.-P.; Chen, M.-H.; Wu, N.; Yao, D.-Y.; Liu, X.-G.; Ji, L.-N.; Mao, Z.-W. Targeting cancer cell metabolism with mitochondria-immobilized phosphorescent cyclometalated iridium(III) complexes. Chem. Sci. 2017, 8, 631-640. [CrossRef] [PubMed]

46. Lo, K.K.W.; Lee, P.K.; Lau, J.S.Y. Synthesis, characterization, and properties of luminescent organoiridium(III) polypyridine complexes appended with an alkyl chain and their interactions with lipid bilayers, surfactants, and living cells. Organometallics 2008, 27, 2998-3006. [CrossRef]

47. Sansee, A.; Meksawangwong, S.; Chainok, K.; Franz, K.J.; Gál, M.; Pålsson, L.O.; Puniyan, W.; Traiphol, R.; Pal, R.; Kielar, F. Novel aminoalkyl tris-cyclometalated iridium complexes as cellular stains. Dalton Trans. 2016, 45, 17420-17430. [CrossRef]

48. Owen, T.; Butler, A. Metallosurfactants of bioinorganic interest: Coordination- induced self assembly. Coord. Chem. Rev. 2011, 225, 678-687. [CrossRef]

49. Lo, K.K.-W.; Law, W.H.-T.; Chan, J.C.-Y.; Liu, H.-W.; Zhang, K.Y. Photophysical and cellular uptake properties of novel phosphorescent cyclometalated iridium(III) bipyridine d-fructose complexes. Metallomics 2013, 5, 808-812. [CrossRef]

50. Li, L.; Szmacinski, H.; Lakowicz, J.R. Synthesis and luminescence spectral characterization of long-lifetime lipid metal-ligand probes. Anal. Biochem. 1997, 244, 80-85. [CrossRef]

51. Li, L.; Szmacinski, H.; Lakowicz, J.R. Long-lifetime lipid probe containing a luminescent metal-ligand complex. Biospectroscopy 1997, 3, 155-159. [CrossRef]

52. Balakrishnan, G.; Rajendran, T.; Senthil Murugan, K.; Sathish Kumar, M.; Sivasubramanian, V.K.; Ganesan, M.; Mahesh, A.; Thirunalasundari, T.; Rajagopal, S. Interaction of rhenium(I) complex carrying long alkyl chain with Calf Thymus DNA: Cytotoxic and cell imaging studies. Inorg. Chim. Acta 2015, 434, 51-59. [CrossRef]

53. Kumar, S.V.; Scottwell, S.O.; Waugh, E.; McAdam, C.J.; Hanton, L.R.; Brooks, H.J.L.; Crowley, J.D. Antimicrobial Properties of Tris(homoleptic) Ruthenium(II) 2-Pyridyl-1,2,3-triazole "Click" Complexes against Pathogenic Bacteria, Including Methicillin-Resistant Staphylococcus aureus (MRSA). Inorg. Chem. 2016, 55, 9767-9777. [CrossRef] [PubMed] 
54. Huang, H.; Zhang, P.; Qiu, K.; Huang, J.; Chen, Y.; Ji, L.; Chao, H. Mitochondrial Dynamics Tracking with Two-Photon Phosphorescent Terpyridyl Iridium(III) Complexes. Sci. Rep. 2016, 6, 1-12. [CrossRef]

55. Chen, Y.; Xu, W.; Zuo, J.; Ji, L.; Chao, H. Dinuclear iridium(III) complexes as phosphorescent trackers to monitor mitochondrial dynamics. J. Mater. Chem. B 2015, 3, 3306-3314. [CrossRef]

56. Huang, H.; Yang, L.; Zhang, P.; Qiu, K.; Huang, J.; Chen, Y.; Diao, J.J.; Liu, J.; Ji, L.; Long, J.; et al. Real-time tracking mitochondrial dynamic remodeling with two-photon phosphorescent iridium(III) complexes. Biomaterials 2016, 83, 321-331. [CrossRef]

57. Qiu, K.; Huang, H.; Liu, B.; Liu, Y.; Huang, Z.; Chen, Y.; Ji, L.; Chao, H. Long-Term Lysosomes Tracking with a Water-Soluble Two-Photon Phosphorescent Iridium(III) Complex. ACS Appl. Mater. Interfaces 2016, 8, 12702-12710. [CrossRef]

58. Lv, W.; Yang, T.; Yu, Q.; Zhao, Q.; Zhang, K.Y.; Liang, H.; Liu, S.; Li, F.; Huang, W. A Phosphorescent Iridium(III) Complex-Modified Nanoprobe for Hypoxia Bioimaging Via Time-Resolved Luminescence Microscopy. Adv. Sci. 2015, 2, 1500107. [CrossRef]

59. Sprouse, S.; King, K.A.; Spellane, P.J.; Watts, R.J. Photophysical Effects of Metal-Carbon c Bonds in Ortho-Metalated Complexes of Ir(III) and Rh(III). J. Am. Chem. Soc. 1984, 106, 6647-6653. [CrossRef]

60. Hedberg, Y.; Gustafsson, J.; Karlsson, H.L.; Moller, L.; Wallinder, I.O. Bioaccessibility, bioavailability and toxicity of commercially relevant iron- and chromium-based particles: In vitro studies with an inhalation perspective. Part. Fibre Toxicol. 2010, 7. [CrossRef]

61. Demas, J.N.; Crosby, G.A. The Measurement of Photoluminescence Quantum Yields. A Review. J. Phys. Chem. 1971, 75, 991-1024.

62. O'Brien, J.; Wilson, I.; Orton, T.; Pognan, F. Investigation of the Alamar Blue (resazurin) fluorescent dye for the assessment of mammalian cell cytotoxicity. Eur. J. Biochem. 2000, 267, 5421-5426. [CrossRef]

63. Rampersad, S.N. Multiple Applications of Alamar Blue as an Indicator of Metabolic Function and Cellular Health in Cell Viability Bioassays. Sens. Basel 2012, 12, 12347-12360. [CrossRef] [PubMed]

64. Hamid, R.; Rotshteyn, Y.; Rabadi, L.; Parikh, R.; Bullock, P. Comparison of alamar blue and MTT assays for high through-put screening. Toxicol Vitro 2004, 18, 703-710. [CrossRef] [PubMed]

(C) 2020 by the authors. Licensee MDPI, Basel, Switzerland. This article is an open access article distributed under the terms and conditions of the Creative Commons Attribution (CC BY) license (http://creativecommons.org/licenses/by/4.0/). 